\title{
The Rise of Cats and Madness: III. The Nineteenth Century
}

\subsection{The King's Madness}

Nineteenth-century England saw a marked increase in both the status and the number of cats as pets. All classes of society welcomed cats to their households, and a picture of a cat by the fireside became an image for the ideal English home. During the same years, the number of insane persons in England increased dramatically. In 1829 , the first reliable national census counted 8,941 insane persons or 0.79 per 1,000 population. In 1915 the census counted 140,461 insane persons or 3.98 per 1,000 population, a fivefold increase in 86 years.

The insanity of King George III shocked England and permanent1ly altered the way madness was viewed. As noted by British historians Ida Macalpine and Richard Hunter, "No longer could insanity be equated with ignorance or sin or superstition. If it was possible for the highest in the land to be struck down after an utterly blameless life of devotion to duty...surely such an illness could not be anything but natural, demanding of sympathy and amenable to medicine as any other?" [1]

The king recovered from his first episode of psychosis after 5 months, and the archbishop of Canterbury composed a prayer of thanksgiving. In retrospect, the cause of the king's insanity was almost certainly acute intermittent porphyria, a rare genetic disease with both physical and psychiatric symptoms. King George had additional attacks in 1801, 1804, and 1810 by which time he was largely blind, deaf, and senile, and he finally died in 1820 .

It was during King George's reign that England laid the groundwork for becoming a nineteenth-century superpower. Lord Nelson defeated the Spanish fleet in 1797 and the French fleet the following year, thus ruling the seas. By the time of the king's death, England had colonized much of the West Indies, parts of Canada, Sierra Leone and Gambia in West Africa, Ceylon and parts of India, and Java. Despite the loss of its American colonies, the sun never set on the British Empire. The trade with its colonies, in turn, stimulated industrialization at home where cottage industries such as textile manufacturing moved to factories driven by water 
power and steam engines. As the nineteenth century advanced, England became the wealthiest country on earth.

One consequence of this increasing wealth was a rapidly expanding middle class with money to spare and aspirations for living like the upper class. One symbol of upper-class living was the keeping of pets, especially dogs. As noted by Ingrid Tague in Animal Companions: Pets and Social Change in Eighteenth-Century Britain, the English middle class had traditionally regarded pet-keeping as "a wasteful extravagance... at best a useless luxury, at worst it was actually sinful." However, "by 1800 attitudes had changed so much that many people had come to regard the love of pets as a sign of moral virtue rather than corruption." Hundreds of London street traders offered live animals, especially dogs, for sale. Books on dogs and products such as Spratts Patent Meat "Fibrine" Dog Cakes ("As supplied to the Royal Kennels") became available. As Harriet Ritvo noted in The Animal Estate, "by the middle of the nineteenth century what has been called the Victorian cult of pets was firmly established" [2,3].

The cult of pet-keeping was called "Victorian" for good reason. Queen Victoria, the only child of the fourth son of King George III, ascended the throne in 1837 and proceeded to set new standards for royal pet-keeping. During her reign she had 88 pets, all named, including 2 Shetland ponies given to her by King Victor Emmanuel of Italy and 2 Tibetan goats, a present from the Shah of Persia. Most of her pets were dogs of various breeds, and she is said to have "had portraits painted of every one of her pampered canines" [4].

\subsection{Nineteenth-Century Cats}

Queen Victoria also kept a few cats, most notably a Persian named "White Heather." The fact that the queen kept cats would certainly have helped negate any lingering stigma associated with their diabolic past. In her book $\mathrm{Cat}$, Katherine Rogers noted that "cats were widely appreciated as pets in the nineteenth century, but they did not contribute to their owners' prestige like dogs or horses." Others agree that at this time "cats were often classed with rabbits and cavies (guinea pigs) as lesser fancy animals and pets of the working man" [5-7]. Nevertheless, many well-known English people owned cats. Florence Nightingale, for example, owned more than 60 cats in her lifetime and claimed that they "possessed much more sympathy and feeling than human beings" [5-7].

Paintings from this period illustrate how the cat was viewed. Walter Crane, an English artist and illustrator of children's books, placed their family cat beside the fireplace in a portrait of his wife (Fig. 5.1). A book on life in the English countryside in the nineteenth century emphasized the importance of "the cat by the fireside or the canary singing in its cage" as symbols of "the comfort of the home." Katherine Rogers agreed that during the nineteenth century the cat became identified "with the Victorian ideal of Home... It became an embodiment of domestic virtue." For example, The Happy Home, a religious tract, was illustrated with a picture of a father 
Fig. 5.1 Walter Crane, "At Home: A Portrait", 1872, Tempora on paper. A cat by the fireside became a symbol of an ideal British home. (Image courtesy of Leeds Museums and Galleries (Leeds Art Gallery) U.K. Copywrite: Leeds Museums and Galleries/ Bridgemen Images)

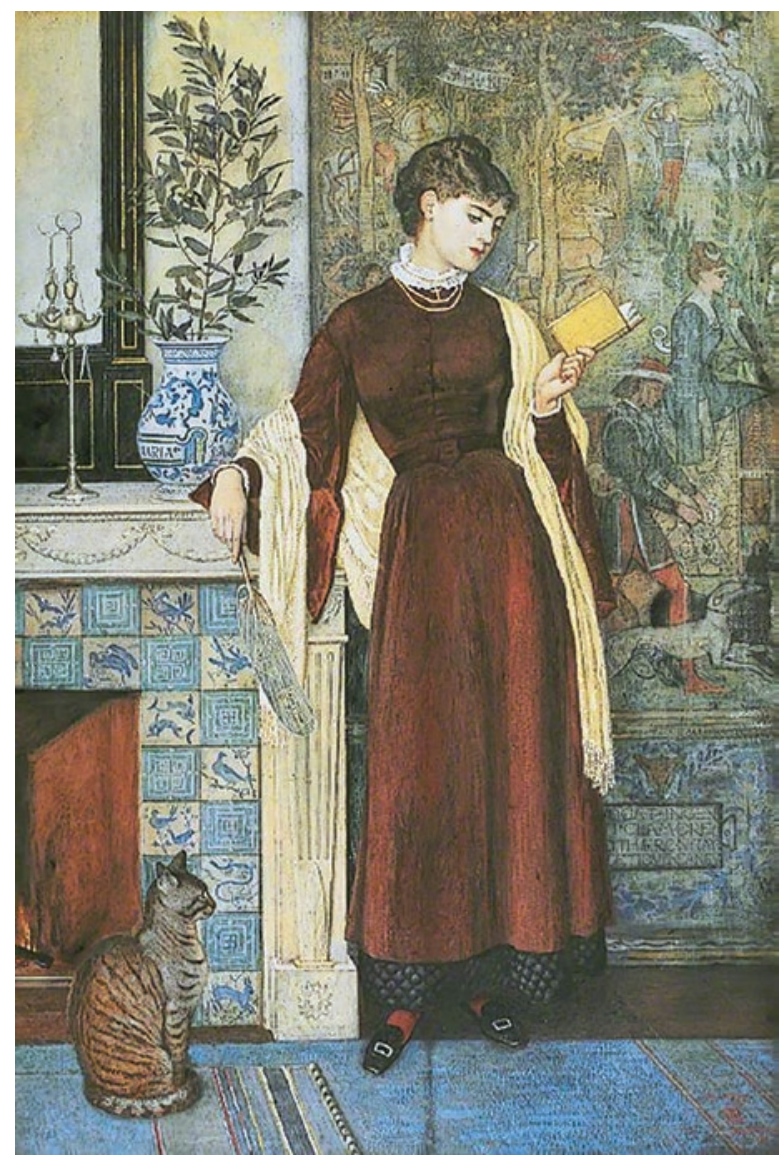

reading to his wife and four children with a cat standing in the foreground, "obviously also listening attentively" [8].

At this time cats were also increasingly associated with women, especially young women and female children. French painter Louis-Leopold Boilly painted a 2-yearold girl holding a cat. An 1835 article in a popular London magazine described children at play, "dressing themselves, or a favorite dog or kitten, in the most ludicrous and fanciful attire." Ford Madox Brown painted his daughter picking flowers with a cat at her feet. Another aspect of femininity was the association of cats with sexuality, as depicted by the French painter Edouard Manet in his 1862 portrait of "Olympia," a prostitute with a cat. In Beastly Possessions, Sarah Amato claims that at this time "grown men were not pictured with cats," which makes Sir John Everett Millais' 1850 portrait of a man holding a cat unusual $[9,10]$.

As had been true in the eighteenth century, writers and especially poets continued to be among the most enthusiastic cat lovers in the nineteenth century. Robert Southey, poet laureate of England from 1813 until his death in 1843, was an example. He kept many cats at his home at Keswick in the Lake Country, a home he 
shared with the family of Samuel Taylor Coleridge and which was regularly visited by Byron, Keats, Shelley, and Scott among others. Southey's son later wrote how his father enjoyed naming his cats:

He rejoiced in bestowing upon them the strangest appellations; and it was not a little amusing to see a kitten answer to the name of some Italian singer or Indian chief, or hero of a German fairy tale, and often names and titles were heaped one upon another, til the possessor, unconscious of the honour conveyed, used to 'set up his eyes and look' in wonderment.

When one of his favorite cats died, Southey wrote to his friend Grosvenor Bedford who was a fellow lover of cats:

\begin{abstract}
Alas, Grosvenor, this day poor Rumpel was found dead, after a long and happy a life as cat could wish for, if cats form wishes on that subject. His full titles were: The Most Noble, the Archduke Rumpelstilszchen, Marcus Macbum, Earl Tomlefnagne, Baron Raticide, Waowhler and Scratch. There should be a court-mourning in Catland, and if the Dragon (your pet cat) wear a black ribbon around his neck, or a band of crape a la militaire round one of his fore paws it will be but a becoming mark of respect...I believe we are each and all, servants included, more sorry for his loss, or rather more affected by it, than any one of us would like to confess $[11,12]$.
\end{abstract}

John Keats wrote a "Sonnet To A Cat" as well as a tribute to the aging cat of a friend: "To Mrs Reynold's Cat." Percy Bysshe Shelley's first known poem was "Verses On a Cat," and he was once quoted as saying: "When my cats aren't happy, I'm not happy. Not because I care about their mood, but because I know they are just sitting there, thinking up ways to get even." George Gordon, Lord Byron, owned five cats at one time along with eight dogs, three monkeys, and a pet bear $[13,14]$.

Sir Walter Scott was said to have "loved all his pets and particularly pampered his cats," especially his favorite named "Hinx." He wrote to a friend: "Ah! Cats are a mysterious kind of folk. There is more passing in their minds then we are aware of. It comes no doubt from their being too familiar with warlocks and witches." William Wordsworth wrote a poem "See The Kitten on the Wall" and was quoted as saying that a kitten "is infinitely more amusing than half the people one is obliged to live with in this world." Algernon Swinburne was said to be "devoted to cats," especially his favorite named "Atossa," and wrote a poem, "To a Cat." John Clare, whose poetry celebrated the English countryside, included cats in several of his poems, including one titled "The Cat Runs Races with Her Tail" [15, 16].

A biographer of William Blake noted that "Blake always preferred cats to dogs." Blake, who was an artist as well as a poet, painted six watercolors to illustrate Thomas Gray's "Ode On the Death of a Favorite Cat," a poem about the drowning of Horace Walpole's cat. Charles Dickens owned several cats, including William which was obligingly renamed Williamina after it gave birth to kittens. When his cat named Bob died, Dickens had one paw stuffed and used it as a letter opener. He was quoted as saying: "What greater gift than the love of a cat." Although he personally liked cats, they are said to be "menacing in his novels." In Bleak House, for example, the large gray cat "is deeply disquieting as she...slinks reluctantly from a dead 
man's room...She embodies the predacity that Dickens saw throughout his society" [17].

The Bronte sisters were also known as cat lovers. In 1842 Emily wrote an essay on "The Cat" in which she noted: "I can say with sincerity that I like cats, also I can give you very good reasons why those who despise them are wrong." According to Katherine Rogers, Anne and Charlotte Bronte "introduced cats into their novels to mark the difference between sensitive people, who consider the feelings of an animal regardless of its conventional status, and obtuse ones, who despise cats as the associates of women and peasants" [18].

It should be noted that England was not unique in the attraction of its writers and other artists to cats. Katherine Rogers claimed that "it would be hard to find a major nineteenth-century French writer who was not particularly fond of cats." These included poets Charles Baudelaire, Thèophile Gautier, and Stephane Mallarme and the historian and critic Hippolyte Taine. Taine described himself as the "friend, master, and servant" of three cats, and he dedicated 12 sonnets to them. He also was quoted as saying: "I have studied many philosophers and many cats. The wisdom of cats is infinitely superior." Rogers noted that "cats with their traditional demonic associations were a perfect symbol for the artist's rejection of conventional standards and assumptions... A taste for what is demonic and forbidden, in cat as in artist, indicated superiority because it proved one's ability to see through the obtuse complacency of ordinary people" $[19,20]$.

Thus, by the latter half of the nineteenth century, cats had become respectable as pets. It was not only eccentric ladies who favored cats, such as "Mrs. Greggs of London who bequeathed 150 pounds per annum so that a trusted black servant could continue to care for her 86 cats." Cats had been lauded by prominent intellectuals such as Samuel Johnson, leading poets such as Robert Southey, and popular novelists such as Charles Dickens and the Bronte sisters. Whereas cats had once been burned as representations of Satan, they had risen from the ashes and assumed a proud place beside the fireplace as representatives of a proper English home [21].

Perhaps nothing symbolized the achievement of feline respectability more than the first English cat show. It took place at London's Crystal Palace on July 16, 1871, organized by Harrison Weir, an artist who was interested in different cat breeds. There were 160 caged entries, with Weir and his brother acting as judges. The cat show was not only the first such show to be held in England but probably in the world. It marked a new relationship between cats and humans. The cat show became an annual event in London and several other English cities and led to the chartering of a national cat club in 1887 with "many well-known people as members, life members, or associates." One of the main purposes of the club was to keep a national studbook and register "in which are registered pedigrees and championship wins" from the cat shows. Thus, each registered cat, which was given a unique number for one shilling per cat, was listed by its sire and dam as well as by its owner. By 1900 there was said to be 2000 registered cats in the studbook, one of which was "valued at 3500 pounds sterling — as much as the price of a first-class race horse." Felis silvestris, which had begun hanging around early agricultural settlements 10,000 years earlier, had truly arrived socially by the late nineteenth century when people started 
keeping records of its parentage. The cat had become not merely respectable but also respected [22].

By the close of the nineteenth century, cats had become increasingly popular as pets. One contemporary source estimated 350,000 cats for all of England; another estimated 400,000 of which half were said to be "unattached," for London alone. And they were popular: "It is certain that they [cats] have more really friends there than in any other country... Queen Victoria and the Princess of Wales, and indeed many members of the nobility are cat lovers, and doubtless this fact influences the general sentiment in England." The keeping of cats and other pets was no longer confined to the upper or even middle classes; "even very poor families between 1870 and 1914 participated in these new consumption patterns...[including] the ownership of pets" [23-27].

One measure of the increasing popularity of cats at this time was the increased use of them in advertisements to sell products. According to a history of cats, "the 1850s would prove to be the beginning of the boom, for cats would be seen everywhere until the late 1920s." Pictures of cats were seen on advertisements for "soap, thread boxes, games, hosiery, stove cleaners, rat poison, oils, and cigar boxes." Indeed, cigars became strongly associated with cats with the introduction of the "Me-ow Label in 1886, Tabby Cigars in 1894, Old Tom in 1900, White Cat in 1908, and Pussy in 1910-1916" [28].

\subsection{The Cats of Writers and Artists}

The respectability of cats was also accelerated during the late nineteenth and early twentieth centuries by their continued embrace by writers and artists. In England an important contributor was Beatrice Potter who in 1902 had published The Tale of Peter Rabbit which became a classic. In 1907 she followed this with The Tale of Tom Kitten, a study about a mother cat—Tabitha Twitchit—and her three children, Tom and his sisters Moppet and Mittens. Subsequently Potter published a Tom Kitten painting book for children, and Tom and other characters in the story were merchandised as toys. The Tale of Tom Kitten reinforced the emerging belief that cats were especially appropriate companions for small children. As the French writer Champfleury noted, "The cat is the nurse's favorite animal, and the first living creature where utterances strikes the ear of infancy... a baby falls asleep with a fantastic image of the cat impressed upon its brain" [29].

Just as the writers extolled the virtues of cats in the nineteenth and early twentieth centuries, so too did the artists. Champfleury had written: "Refined and delicate natures understand the cat. Women, poets and artists hold it in great esteem, for they recognize the exquisite delicacy of its nervous system." Similarly, Caroline Bugler noted: "It has always been the cat's personality, behavior and sensuality that has fascinated the most advanced painters, literary figures and musicians" [30, 31].

Among the best-known paintings of this period that included cats were those of Pierre-Auguste Renoir. His "Woman with a Cat" (1874), "Sleeping Girl with a Cat" (1880) (Fig. 5.2), and "Julie Manet with a Cat" (1887) are examples. Other French 
Fig. 5.2 Pierre-Auguste Renoir, "Sleeping Girl", 1880 , Oil on canvas. Renoir included cats in other female portraits as well. (Image courtesy of The Clark Art Institute, Williamstown, MA, 1955.598, www.clarkart. edu Public Domain.)

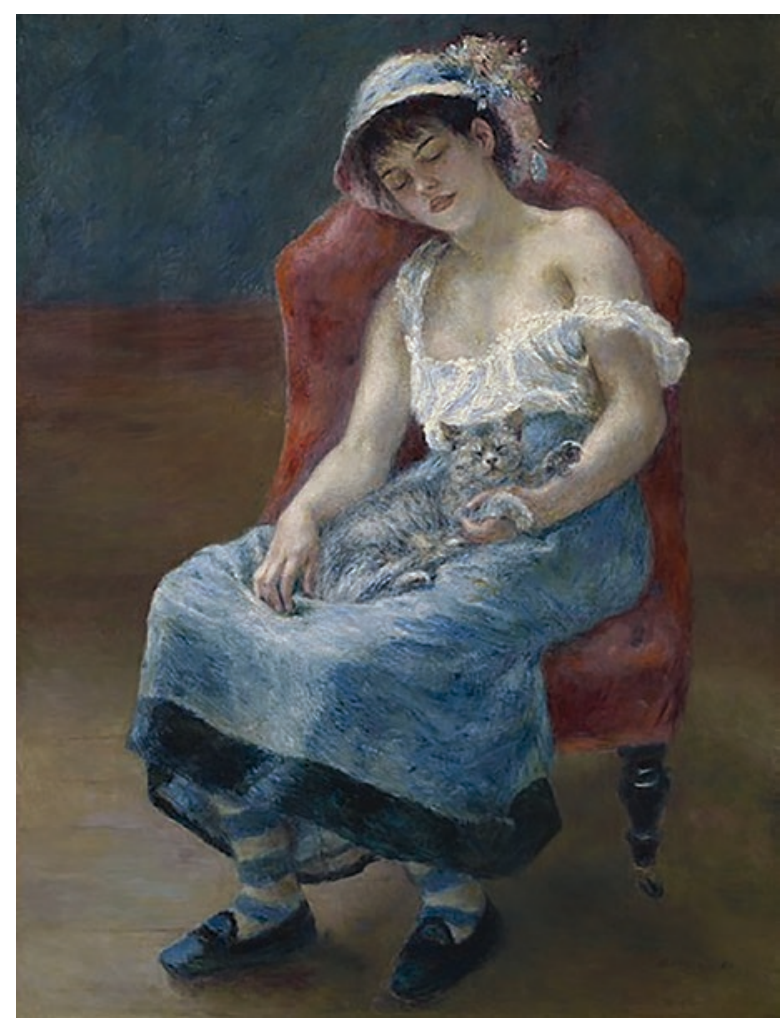

Impressionists such as Berthe Moriset's "Young Girl with a Cat," (1892) and Pierre Bonard's "Woman with a Cat," (1912) also juxtaposed young women and cats. Philip Steer, among the few English Impressionists, also painted an elegant woman with her cat in "Hydrangeas" (1901).

\subsection{Increasing Insanity}

Claims that madness was increasing in England had been widespread even before King George III had become insane in 1788, and his illness exacerbated such fears. In 1792 clergyman and physician William Pargeter, in response to the king's illness, published his Observations on Maniacal Disorders. He described insanity as "the hideous malady which so amazingly prevails at this day" and said that "the frequency of this disease renders it truly alarming. . . . [it] has arrived at the height of its dominion." His eloquent description of the consequences of insanity is worth quoting:

It would be almost too shocking to portray the real features of this terrible complaint ... the situation of a fellow creature destitute of the guidance of that governing principle, reasonwhich chiefly distinguishes us from the inferior animals around us.... View man deprived 
of that noble endowment, and see in how melancholy a posture he appears. He retains indeed the outward figure of the human species, but like the ruins of a once magnificent edifice, it only serves to remind us of his former dignity, and fills us with gloomy reflections of the loss of it [32].

Among the best-known English physicians in the closing years of the eighteenth century was Bethlem Hospital's John Haslam, labeled by British psychiatrist Denis Leigh as "by far the most original and discerning writer on psychiatry in the period 1798 to 1828." In 1798 Haslam published his Observations on Insanity, which was widely circulated throughout Europe and issued in a second edition in 1809, at which time it was also praised in the popular Quarterly Review. Haslam noted that "the alarming increase of insanity, as might naturally be expected, has incited many persons to an investigation of this disease. . . In our own country more books on insanity have been published than in any other" [33-35].

Haslam was especially impressed by the increasing number of individuals who were becoming insane at a young age. In 1789 Andrew Harper, in The Economy of Health: A Treatise on the Real Cause and Cure of Insanity, had written "that young people are hardly ever liable to insanity and that the attack of this malady seldom happens before an advanced period of life." Yet Haslam described cases of this form of insanity as if they were something comparatively new: "There is a form of insanity which occurs in young persons. . . . This disorder commences about, or shortly after, the period of menstruation." Haslam proceeded to provide the first unequivocal English description of what we now label schizophrenia and in 1810 published an entire book on another case, Illustrations of Madness: Exhibiting a Singular Case of Insanity [36, 37].

In addition to describing schizophrenia, Haslam also provided remarkably clear descriptions of bipolar disorder (including the rapid-cycling kind), postpartum psychosis, postvaccinal encephalitis presenting with psychosis, alcoholic psychosis, and psychosis secondary to syphilis. Haslam's Observations on Insanity was judged by Denis Leigh to be "a most outstanding piece of work, surpassing in merit any previous publication both in England or on the continent" [38].

In the opening years of the nineteenth century, the consensus of Pargeter and Haslam was echoed by many of their colleagues. In his Practical Observations on Insanity, Joseph Cox noted that "insanity is unfortunately not only frequent but said to be peculiarly endemical to England." William Stark added that the loss of reason is "the heaviest calamity incident to our race." Thomas Trotter claimed that "the last century has been remarkable for the increase of a class of disease but little known in former times" and estimated that "nervous disorders" had replaced fevers as the most common affliction. And in 1808 John Reid, a London physician, wrote in the Monthly magazine that "the English malady, by its visible and rapid progression, renders itself every day more deserving of the title...Madness strides like a Colossus over the island" [39-42].

By this time parliament had also become concerned and, for the first time in English history, appointed the "Select Committee of the House of Commons, appointed to inquire into the state of lunatics." The impetus for parliament's actions 
was claims that insanity was increasing as well as an increasing number of highly publicized acts by mad people. The most egregious of these was James Hadfield's attempted killing of King George III in 1800. At his trial Hadfield said that he had done so by God's command to bring about the Second Coming; the irony of a madman attacking the king who was himself intermittently mad was not lost on the public. Hadfield was confined to Bethlem Hospital where he demonstrated his continuing dangerousness by killing another patient.

The parliamentary hearings of the Select Committee in 1807 focused on the number of insane people in England, especially those being held in workhouses and jails. The sheriff of Gloucestershire, for example, testified that he had seen "poor lunatics who have been fastened to the leg of a table within a dwelling house; others chained to a post in an outhouse." He noted an increasing number of insane persons being held in jails and added: "I think jails, however well regulated, are places highly improper for the custody, and inconsistent with the cure of lunatics" [43].

The Select Committee in 1807 also attempted to collect data from each county regarding the total number of mad people in workhouses and jails. The results, however, were highly variable and unreliable. It was clear that many counties were unwilling to share information with parliament on what had been regarded up to that time as a local problem. Some counties claimed that they had no insane persons at all in workhouses or jails, and others listed only a fraction of them. For example, Norfolk claimed to have 22 such people but an independent second count found 112. In 1810 Richard Powell, secretary of the commissioners of the College of Physicians, made another attempt to quantify the increasing insanity by using admissions to madhouses over time. In what was apparently the first statistical study of insanity, Powell showed a sharp rise in admissions between 1770 and 1809 and concluded that "the increase must actually have been very considerable, though we cannot ascertain its exact proportion" [44, 45].

The outcome of the Select Committee report was passage of "An Act for the Better Care and Maintenance of Lunatics," better known as the County Asylum Act of 1808 , by which counties were encouraged, but not required, to build public insane asylums, to be paid for with local taxes. According to Leonard Smith, "the Act was remarkable in a number of ways, not least because it signified, whether by design or by accident, an unusually direct intervention by the state in health and welfare provision." This was, it should be noted, the first of 20 parliamentary acts and amendments concerning insane persons, idiots, and insane asylums that would be passed during the nineteenth century. As John L. Crammer observed, "an astonishing amount of Parliamentary time was spent on this subject in the nineteenth century." Similarly, Vieda Skultans noted that "the number of Bills, reports of select committees and inquiries relating to lunacy rose from a mere handful in the eighteenth century to seventy-one between the years 1801 and 1844" [46-48].

The first of the new county asylums opened in Nottinghamshire in 1812, followed by others in Bedfordshire, Norfolk, and Lancashire. By 1824 the number of county asylums had increased only to 8, ranging in size from 40 beds in Bedfordshire to 250 beds in Lancashire. The total number of beds in these county asylums was 932 to serve an 8-county total population of 3.4 million, suggesting that authorities 
expected utilization of the asylums to be low. And in some counties, it initially was; the Gloucestershire Asylum, which opened in 1823 with 110 beds, still had only 31 patients 6 months later [49].

In many counties, there was considerable resistance to building an asylum, both because of costs and because of doubts regarding need. The Gloucestershire Asylum, for example, had been first proposed in the 1790s but, because of local resistance, did not become a reality until 1823. In Middlesex, "several parishes lodged objections on grounds of cost," and those in the vicinity of the proposed asylum objected that the "cries and noises of the unhappy inmates" would be unsettling to them. In Suffolk there were "concerted local campaigns of petitions and protests" that delayed the asylum's opening [50].

In addition to the building of public asylums, private asylums also increased in the early years of the nineteenth century. In 1798 there had been 42 provincial and metropolitan "licensed houses," but by 1815 this number had increased to 72. Most of them were very small, and the annual admissions for all of them together averaged less than 500 a year until 1810-1815, when these admissions doubled.

\subsection{What Was Causing the Increase?}

Following the report of the Select Committee of 1807 and subsequent passage of the County Asylums Act, claims continued to be made that madness was increasing. Bryan Crowther, in Practical Remarks, published in 1811, called insanity "an affection so rapidly becoming prevalent among all orders of society." George Hill, in An Essay on the Prevention and Cure of Insanity, published in 1814, said that insanity "is certainly not to be rated among our declining diseases" and noted the contemporary outpouring of publications on the subject. Louis Simond, an American who made a 2-year tour of England in 1810 and 1811, published his observations in 1815 , noting that "madness appears to be fatally common in Great Britain" and that this high incidence existed despite the fact that "the qualifications required for acknowledged insanity, are by no means easily attained in England, where a greater latitude is granted for whims, fancies, and eccentricities, than in other countries" [51-53].

Increasingly, however, in the early years of the nineteenth century, public discussion shifted from the question of whether madness was increasing to why it was increasing. A definitive answer to that question had been offered in 1782 by Thomas Arnold, an Edinburgh-trained physician who ran a private asylum in Leicester. His two-volume Observations on the Nature, Kinds, Causes and Prevention of Insanity, Lunacy or Madness was widely praised, including by James Boswell, and included a chapter on the question of increasing insanity.

Arnold acknowledged that "instances of Insanity are, at this day, amazingly numerous in this kingdom-probably more so than they ever were in any former period." The "most powerful causes" of insanity, Arnold claimed, were "religion, 
love, commerce, and the various passions which attend the desire, pursuit, and acquisition of riches-every species of luxury - and all violent and permanent attachments whatsoever." As evidence for his theory, Arnold compared England's high rate of insanity to that in France which had not yet had its revolution and which Arnold claimed had a much lower rate of insanity. According to Arnold, under French Catholicism, "whose chief characteristic is superstition," the "pardon for sins of all sorts and sizes is so easily obtained [as] in every popish country that few true believers . . . can be supposed to be much troubled with religious melancholy." Similarly, "love, with them, is almost wholly an affair of art;-it has more of fancy than passion; and is rather an amusement of the imagination, than a serious business of the heart." Regarding "the desire, and prospect, of acquiring riches . . . there can be but little hope of attaining riches in a land of slaves, where the bulk and strength of a nation is depressed and impoverished . . . being subject to the will of an absolute monarch," in contrast to England's "happy land of liberty." Arnold thus concluded: "All these circumstances being taken into the account, it seems not improbable that this disorder is not only much more prevalent in England than in France, but more peculiar to this than to any other country. For even waving the other considerations just enumerated, an excess of wealth and luxury, in which perhaps no nation upon earth can vie with this, seems to entitle us to an abundant share of the curse which appears too plainly to be entailed upon their possessors" [54].

It is surely a peculiar form of patriotism to view insanity as evidence of a superior civilization but that is what Arnold was arguing. Not only was insanity increasing, but the English should be proud of that fact. Arnold noted that "we hear of few or no instance of Insanity among barbarous nations, whether ancient or modern." Insanity was also rare, he claimed, in Scotland and in the poorer areas of Wales, regions in which "wealth and luxury are but little known." Insanity, in brief, was a marker of an advanced civilization [55].

Arnold's explanation for the increasing insanity became widely accepted in the closing years of the eighteenth and early nineteenth centuries. England's industrial revolution was expanding rapidly with a doubling of the real national output between 1780 and 1800 and a tenfold rise in patents for new inventions. Thus in 1788 William Rowley claimed that "in those kingdoms where the greatest luxuries, refinements, wealth, and unrestrained liberty abound, are the most numerous instances of madness." The following year Benjamin Falkner echoed both Arnold and Rowley: "The rapidity with which the disorder has spread over this country, within the last fifty years, may be attributed, in great measure, to the increase of luxury...Inordinate desires, and the indulgence of inordinate passions." In 1802 Thomas Beddeos spoke about nations "civilized enough to be capable of insanity." In 1816 David Uwins wrote that "luxury invites excess and excess spells madness...In proportion as man emerges from his primeval state, do the Furies of disease advance upon him." In 1824 Alexander Morison noted that "insanity increases with civilization." Finally, in 1837, William A.F. Browne agreed that "with luxury, indeed, insanity appears to keep equal pace" [56-60]. 


\subsection{Madness Among "the Better Sort"}

As the discussion of increasing madness became widespread in nineteenth-century England, there was agreement that some groups of people were more affected than others. This had been noted as early as 1733 when George Cheyne in The English Malady singled out people "of the better sort" as being most susceptible to insanity, specifically "those of the liveliest and quickest natural Parts, whose Faculties are the brightest and most spiritual, and whose Genius is most keen and penetrating, and particularly where there is the most delicate Sensation and Taste, both of Pleasure and Pain." Others at that time had similarly claimed that "lords and ladies, accustomed to luxurious living and idleness... were more liable to what we call neuroses and psychoses than people in the lower ranks" [61].

Echos of Cheyne continued to be heard in the nineteenth century. Lord Simond, the American who visited England, was told that "the rich particularly are most exposed to this calamity [insanity]... madness appears to be fatally common... among the higher ranks." English psychiatrist W.A.F. Browne claimed that the rural poor "is to a great degree exempt from insanity" but the wealthy and educated are especially susceptible because they are exposed to "excitement... and to the formation of habits of thought and action inimical to the preservation of serenity and health." Similarly David Uwins in his book on mental disorders singled out the intellectual avant-garde as being most affected-those who had "pianos, parasols, Edinburgh Reviews, and Paris-going desires." The French were making similar claims. Esquirol claimed that madness was more usually a disease of the rich, while Phillipe Pinel noted that the large asylum in Paris contained a disproportionate number of "priests and monks" as well as "many artists, painters, sculptors and musicians [and] some poets extasized by their own productions" [62-65].

An interest in, and/or personal experience with, madness was endemic among English writers and poets in the nineteenth century. Such interest was presaged in 1796 when Mary Lamb, in an acute attack of mania, killed her mother with a carving knife as they were preparing dinner. Mary, age 31, had had one previous manic episode and suffered additional attacks every year or two for the remainder of her life. Between hospitalizations Mary was cared for at home by her younger brother, Charles, who himself had been hospitalized for a manic attack at age 19 and thereafter had problems with alcohol abuse. Charles and Mary were both writers, he as a widely read essayist whose whimsical creations included "A Dissertation upon Roast Pig" and "A Chapter on Ears." Together they wrote Tales Founded on the Plays of Shakespeare for children, and Mary published a book on Poetry for Children. The specter of madness was ever present for them both. At one point Charles Lamb wrote to his closest friend, Samuel Taylor Coleridge: "Dream not, Coleridge, of having tasted all of the grandeur and wildness of Fancy, till you have gone mad. All now seems to me vapid; comparatively so" [66-68].

Coleridge also had a deep interest in madness, experiencing periods of depression and having been discharged from the army as being insane. The correspondence between Lamb and Coleridge often touched on madness and the mental state 
of their colleagues; for example, "Coleridge, you will rejoice to hear that Cowper is recovered from his lunacy" (May 1776). Coleridge's two best known poems, "Kubla Khan" and "The Rime of the Ancient Mariner," are both said to be about madness. As early as 1813, George Crabbe said of "The Ancient Mariner": "It does not describe Madness by its Effects but by Imitation, as if a painter to give a picture of Lunacy should make his Canvas crazy, and fill it with wild unconnected Limbs and Distortions of features ..." And Michael Shimer wrote: "The Mariner as a mad figure need hardly be argued. So strange is his appearance, behavior, and power that little or no doubt is left to his marked abnormality. . . . The theme of madness originates, of course, in the Mariner's killing of the albatross. . . . It is a manifestation of human irrationality." In his correspondence, Coleridge likened madness to "a fiery hell":

Why need we talk of a fiery hell? If the will, which is the law of our nature, were withdrawn from our memory, fancy, understanding, and reason, no other hell could equal, for a spiritual being, what we should then feel, from the anarchy of our powers. It would be conscious madness-a horrid thought!

For much of his life, Coleridge was also addicted to opium [69-72].

William Wordsworth, England's poet laureate from 1843 to 1850, was close friends with both Lamb and Coleridge, and it was he who suggested to Coleridge to have the Ancient Mariner kill the albatross. Wordsworth was himself subject to periods of depression and was drawn to the subject of insanity. According to Michael Shimer, "During the mental crisis in his own life (roughly between the spring of 1795 and the fall of 1797), Wordsworth wrote a group of poems that explicitly deal with the theme of madness." One of them was titled "The Mad Mother":

A fire was once within my brain;

And in my head a dull, dull, pain;

And fiendish faces one, two, three,

Hung at my breasts, and pulled at me [73].

Robert Southey, poet laureate for 30 years, was Coleridge's brother-in-law. At his home in the Lake Country, he entertained many of the poets of his generation. Among Southey's most popular poems was "Mary, The Maid of the Inn" about a woman who becomes mad. Originally titled "Mary the Maniac," it was widely reprinted in contemporary magazines. Ironically, Southey's wife became insane and spent 3 years in an asylum.

Madness was a major theme in the life of William Blake. Charles Lamb referred to him as "the mad Wordsworth." Southey, after meeting Blake, said: "You could not have delighted in him-his madness was too evident." Whether or not Blake was truly insane has been debated endlessly by his biographers; what is clear is that he regularly experienced visions and communed with spirits. Paul Youngquist argued that Blake "was a poet for whom madness became a major subject. . . Blake made poetry out of pathology. .. . Madness emerges in his poetry as a thematic preoccupation." The Four Zoas, which was not published in Blake's lifetime, has been 
described as "a mythological investigation of madness" with "contemporary clinical parallels in the symptomology of schizophrenia" [74].

Blake was also very interested in the eighteenth-century poets Thomas Chatterton, who committed suicide, and William Cowper, who became insane. He collaborated with Cowper's biographer to produce illustrations for the book. Blake also painted a clearly mad Nebuchadnezzar, based on the biblical Book of Daniel. For "Jerusalem," Blake's greatest poem, one biographer suggested that he incorporated "the shade of Cowper" into the specter that torments the protagonist [75].

George Crabbe, originally trained as a surgeon, became a successful poet and friend of Wordsworth, Byron, and Scott. In 1796 Crabbe's wife became insane following the birth of their third child, and thereafter insanity became a major theme in his work. Among his many portrayals of insanity was "Sir Eustace Grey"; published in 1807, it was set in a madhouse and included extended descriptions of a madman's hallucinations. The poem was "well received in its day," and a reviewer noted: "Mr. Crabbe has, perhaps, been driven to the melancholy contemplation on insanity in all its wild variety of mood, and so, alas! to our misfortune, have we." "Tales," published in 1812, was another portrait of insanity [76-78].

Like Crabbe, John Keats initially trained in medicine before giving it up to be a poet. In Touched with Fire, Kay Jamison described Keats' mood swings and speculated that he might have had bipolar disorder before he died from tuberculosis at 25 . According to Shiner, Keats' literary ballad "La Belle Dame Sans Merci” concerns a "noble mind that has gone mad." Keats also wrote an "Ode on Melancholy" [79].

George Gordon, Lord Byron, was one of the most influential of the English Romantic poets. His close friend Sir Walter Scott wrote of him: "There is something dreadful in reflecting that one gifted so much above his fellow-creatures should thus labour under some strange mental malady that destroys his peace of mind and happiness. . .." Byron's "strange mental malady" was bipolar disorder; throughout his life he suffered from periods of recurrent mania and severe depression, and he ultimately was divorced by his wife on the grounds that he was insane. During one period of depression, he contemplated suicide but was stopped by the realization that "it would have given pleasure to my mother-in-law." The fear of impending insanity haunted Byron, as he wrote to a friend: "I don't know that I shan't end with insanity, for I find a want of method in arranging my thoughts that perplexes me strangely." This preoccupation with madness was reflected in his poetry, as in his description of an insane woman in The Dream. Reflecting on his own madness and that of his fellow poets, Byron said: "We of the craft are all crazy" [80].

In 1816, Byron met Percy Bysshe Shelley. Shelley found Byron "exceedingly interesting" but "mad as the winds." Shelley, in fact, had his own psychiatric problems, including recurrent episodes of depression and apparent hallucinations. Kay Jamison, in Touched with Fire, argued that Shelley, like Byron, had bipolar disorder, although some Shelley scholars do not agree. Shelley and Byron spent much time together between 1816 and 1821, during which time Shelley wrote Julian and Maddalo, a poem about two men (thought to be Shelley and Byron themselves) who visit a friend who has become insane and is incarcerated in a madhouse: 
...The clap of tortured hands,

Fierce yells and howlings and lamentings keen,

And laughter where complaint had merrier been,

Moans, shrieks, and curses, and blaspheming prayers,

Accosted us [81].

Sir Walter Scott was friends with many of the Romantic poets and one of the most widely read writers of his era. Although he suffered from the "black dog" of melancholy, Scott was never insane. However, he "made mental maladies a special study" and immortalized insane women, most prominently as Madge Wildfire in The Heart of Midlothian (1818) and as Lucy Ashton in The Bride of Lammermoor (1819). In the former, Madge is referred to as "Madge of Bedlam" and sings of her time spent there:

In the bonny cells of Bedlam

Ere I was ane and twenty,

I had hempen bracelets strong,

And merry whips, ding-dong,

And prayer and fasting plenty.

One scholar labeled this scene "one of the most poignant scenes in all of Scott's fiction, here is insanity on display . . . the face of madness grimacing at the sane world." Another of Sir Walter Scott's mad heroines, Lucy Ashton, was subsequently the heroine of eight different operas, most notably Gaetano Donizetti's Lucia di Lammermoor (1835), in which Lucia suffers from visual and auditory hallucinations. In the "mad scene," Lucia, overtly insane, kills the man she has just been forced to marry [82-84].

John Clare was a promising young poet specializing in poems of rural England when he developed psychosis. In 1837 he was voluntarily admitted to Dr. Matthew Allen's private asylum in Essex. He experienced auditory hallucinations and grandiose delusions in which he believed himself to be Lord Byron, Lord Nelson, or other famous persons. He told one visitor, "They have cut off my head and picked out all the letters of the alphabet-all the vowels and consonants-and brought them out through my ears." Clare spent 4 years at Dr. Allen's asylum and then 23 additional years at the Northamptonshire Lunatic Asylum, which he characterized as "the land of Sodom where all the people's brains are turned the wrong way." During his extended stay in these asylums, Clare continued writing poems, some of which reflected his despair at being confined and forgotten [85-87].

During the 4 years when John Clare lived at Dr. Allen's private asylum in Essex, Alfred Lord Tennyson lived a short walk away. At the time Tennyson was regarded as one of England's most promising young poets; he would later be appointed poet laureate from 1850 to 1892 . Tennyson had purposefully moved to be near Dr. Allen's asylum to get psychiatric care for one brother, Septimus. Another brother, Edgar, had already become insane and would be hospitalized for 57 years in the York Asylum. According to one biographer "from the time Tennyson was a child...the specter of madness was always to hover over him and often to come dangerously 
near." He regularly visited Dr. Allen's asylum to "study the ravings of the demented at firsthand" and almost certainly would have had conversations with his fellow poet, John Clare. Later Tennyson used mad figures in several of his poems, including "Maud" which was his "favorite poem and one which he loved to recite." A contemporary reviewer described "Maud" as "neither more nor less than the autobiography of a madman...depicted by the hand of a master." And Michael Shimer, in his study of madness in nineteenth-century English poetry, claimed that "the madhouse section of 'Maud'... is probably the most realistic portrayal of insanity that we shall encounter in our study" $[88,89]$.

Madness is also prominent in Charlotte Bronte's 1847 novel Jane Eyre. The heroine goes to Thornfield Hall as a governess and falls in love with the master of the house, Edward Rochester. He proposes marriage, but Jane discovers that he is already wed to an insane woman who is being hidden in the attic. Bronte's description of Mrs. Rochester is that of a dangerous wild animal: "In the deep shade, at the farther end of the room, a figure ran backwards and forwards. What it was, whether beast or human being, one could not, at first sight, tell: it grovelled, seemingly, on all fours; it snatched and growled like some strange wild animal: but it was covered with clothing, and a quantity of dark, grizzled hair, wild as a mane, hid its head and face" [90].

When Charlotte Bronte was later criticized for her brutish depiction of Mrs. Rochester, she responded that she was merely reflecting the reality of some cases of madness "in which all that is good or even human seems to disappear from the mind and a fiend-like nature replaces it." Such a description was consistent with the increasing tenor of the times. As Ann Colley noted in Tennyson and Madness, "Brontë's Mrs. Rochester, locked within the tower of Thornfield Hall," was not merely "a literary convention" but rather reflected that period's preoccupation with madness, "a madness that was a pressing and threatening reality" [91, 92].

An ironic postscript to Jane Eyre was Charlotte Bronte's dedication of the second edition of the book to William Makepeace Thackeray, whom she greatly admired. Unknown to Bronte, Thackeray's wife, Isabella, who had become insane, tried to drown their daughter, and attempted suicide, was being quietly confined in a house in London under the care of two women attendants. Both Mrs. Rochester and Mrs. Thackeray became mad 4 years following their marriages, "both were given to manic bursts of laughter" and "both were at times violent and even homicidal." When Charlotte Bronte learned of Isabella Thackeray's condition, she "was torn between amazement and mortification," apologized to Thackeray, and told a friend that it proved that "fact is often stranger than fiction" [93].

Among all the nineteenth-century poets and writers with an interest in madness, however, none surpassed Charles Dickens. He visited asylums regularly, including asylums in New York and Boston during his 1842 visit to America. He was also remarkably knowledgeable about insanity. His personal library included Robert Burton's Anatomy of Melancholy, John Conolly's On Some Forms of Insanity, Forbes Winslow's The Incubation of Insanity, and W. C. Hood's Suggestions for the Future Provision of Criminal Lunatics [85-87]. The two journals Dickens edited, Household Words and All the Year Round, regularly included articles on madhouses 
and asylum reform. Most importantly, Dickens was close friends with John Conolly, one of the foremost psychiatrists of the mid-nineteenth century, and with two of the lunacy commissioners, Bryan Proctor and John Forster, whose full-time jobs were to inspect madhouses. Forster, in fact, became Dickens's first biographer with his Life of Charles Dickens in 1872. It is likely that the ideas for many of Dickens's mad characters were derived from his conversations with these men [94].

The most notable mad character created by Dickens was published in 1837 as "A Madman's Manuscript," one of the monthly installments of The Pickwick Papers. The story is a strange tale, told in the first person by a madhouse inmate who is being laughed at by visitors peering into his cell. Rather than feeling humiliated, the madman delights in his status and in his ability to terrify others: "Show me the monarch whose angry frown was ever feared like the glare of a madman's eye. . . Ho! Ho! It's a grand thing to be mad!" He then recounts the onset of his illness, "watching the progress of the fever that was to consume [his] brain," the voices screaming in his ears, his attempted murder of his young wife, and then his successful murder of his brother-in-law and subsequent incarceration [95].

In Barnaby Rudge, published 4 years later, Dickens continued this theme. According to one critic, "madness is loosed upon the text from the onset. . . . The novel is, in that sense, a meditation on the perils of growing insanity, insanity always threatening to erupt in violence, and the impotence of traditional asylums such as Bethlem Hospital to cope with that growth." In the novel a rumor is spread that a mob, led by Lord Byron, who himself is depicted in the book as having the symptoms of insanity, "meant to throw the gates of Bedlam open, and let all the madmen loose. This suggested such dreadful images to people's minds, and was indeed an act so fraught with new and unimaginable horrors in the contemplation, that it beset them more than any loss or cruelty of which they could foresee the worst, and drove many sane men nearly mad themselves" $[96,97]$.

Charles Dickens continued to depict mad characters in his novels throughout his career. One of the best known is David Copperfield's Mr. Dick, who believes he has things in his head that came from the head of King Charles I and were transferred to him when the king was beheaded in 1649. In 1851 Dickens visited St. Luke's Asylum in London shortly after Christmas, later publishing a description of the holiday dance held for patients as "A Curious Dance Round a Curious Tree," in which he praised the nonuse of restraints as part of the increasingly popular moral treatment. And in 1857, in The Lazy Tour of Two Idle Apprentices, published with Willkie Collins, Dickens described a fictional visit to an insane asylum, including a poignant description of patients standing idly on the wards of the asylum: "Long groves of blighted men-and-women trees; interminable avenues of hopeless faces; numbers, without the slightest power of really combining for any earthly purpose; a society of human creatures who have nothing in common but that they have all lost the power of being humanly social with one another" $[98,99]$.

Willkie Collins, with whom Dickens wrote The Lazy Tour of Two Idle Apprentices was well known in his time as the author of what were called sensation novels. According to David Oberhelman's thesis on the Victorian novel, these novels exhibited "a mania for madness itself, ... producing a veritable Bedlam of madmen and 
madwomen. . . Madness and the system of private lunatic asylums ... are almost ubiquitous plot elements in the sensation novels. ... Wrongful confinement ..., the corruption of 'mad-doctors,' and the threat of hereditary madness become some of the most lurid nightmares [in the works of Willkie Collins and his contemporaries]" [100].

Collins' best-known novel was The Woman in White about a woman who escapes from an asylum. It was so popular that it created new marketing strategies, including a line of Women in White clothing and perfume. Armadale, published by Collins in 1866 , is about "Dr. Downward," an unethical psychiatrist who confines people inappropriately in his private asylum. According to Oberhelman "various aspects of madness dominate the prose of the text. . . Madness so saturates the text that any debate over figurative or literal uses of the term is rendered meaningless. ... It illustrates the true epidemic proportions of madness in the 1800s" [101].

Another widely read sensation novel of the early 1860s was Lady Audley's Secret, written by Mary Elizabeth Braddon. Mrs. Braddon had a special interest in insanity, since she was living with, but could not marry, publisher John Maxwell, whose wife was insane and confined to an asylum. In Mrs. Braddon's book, the "secret" is that Lady Audley is insane, a fact slowly revealed in the novel through her bigamy and subsequent murder of one of her husbands. In her confession at the end of the book, Lady Audley says: "I killed him because I AM MAD! because my intellect is a little way on the wrong side of that narrow boundary-line between sanity and insanity" $[102,103]$.

Although most of the available evidence regarding madness among "the better sort" comes from writers, especially poets and novelists, there were also a few artists who became mad in the late eighteenth and early nineteenth centuries. John Robert Cozens was a well-known British watercolorist who became psychotic at age 42, was hospitalized in Bethlem Hospital, and died 3 years later. Lemuel Abbott, a prominent portrait painter whose painting of Lord Nelson hangs at 10 Downing Street, was declared insane at age 38 and treated by Dr. Thomas Munro. James Gillray, a caricaturist who had been called "the father of the political cartoon," became suicidal and psychotic at age 57 although alcohol abuse was a contributing factor. Finally, Richard Dadd, regarded as one of Britain's most promising young artists, developed a paranoid psychosis at age 25 and in 1842 killed his father, who he believed to be the devil in disguise. He continued painting, including a work that hangs at the Tate Gallery, while hospitalized until his death at age 68 [104].

\subsection{Was Insanity Really Increasing?}

During the middle years of the nineteenth century, as English writers were incorporating madness into their writings and, in some cases, experiencing it, the question of whether or not insanity was increasing came again to the fore. The immediate precipitant was a claim in 1820 that, contrary to popular beliefs, madness was not increasing. The person who made the claim was George Man Burrows, a prominent London physician who ran a private madhouse in Chelsea. Burrows was deeply 
involved in establishing the legal rights of the medical profession and had played a leading role in persuading parliament to pass the Apothecaries Act of 1815 which gave physicians control over the prescribing of medicines. Burrows also fought to establish insanity as the legal province of physicians. Thus he had both a professional and a financial interest in demonstrating the success of the medical profession in caring for the mad. Increasing insanity clearly would not be good for the reputation of the profession $[105,106]$.

In his 1820 book entitled An Inquiry Into Certain Errors Relative to Insanity and in Commentaries, published 8 years later, Burrows reviewed available data on the number of insane persons in England and Ireland and concluded that the total number was approximately 6,000, similar to the estimate derived for England from the Select Committee survey of 1807. He acknowledged that "foreigners of all countries pronounce insanity as the opprobrium of England" and that "the popular opinion is that insanity is alarmingly prevalent." He argued strongly, however, that insanity was "not an increasing malady" and in 1828 even argued that it was decreasing in incidence [107].

Burrows offered two reasons for his belief that insanity was not increasing. The first was the fact that insane asylums, presumably including the one he owned, were effective in treating this condition, and therefore, ipso facto, insanity had to be decreasing. He explained it as follows: "I have, therefore, no other ground for my conviction of the general diminution in the number of lunatics, than the pleasing and incontrovertible fact, that wherever asylums for insane persons have been established, from the superior mode of treatment, both medical and moral, the number who recover is much greater than heretofore; and, consequently, that the aggregate number of the insane must be lessened." Burrows's second reason for denying any increase in insanity - and even arguing for a decrease — was that increasing insanity would be a national scandal and therefore it should not be true: "Hence, as the respective exciting causes vary, so likewise must everywhere the number of lunatics. But does it thence follow that insanity must be increasing? A conclusion so humiliating cannot be entertained without the most painful reflections; nor, if it be really so, can the consequences be indifferent, even in a national point of view?" [108]

Burrows's conclusions were quoted by some contemporary psychiatrists and others who did not believe, or did not want to believe, that insanity was increasing. More than 150 years later, historians Ida Macalpine and Richard Hunter, in George III and the Mad Business, would cite Burrows as having definitively proven that insanity had not increased in the early nineteenth century: "The question whether insanity was on the increase Dr. Burrows therefore answered with a definite no. ... This particular ghost had at last been laid to rest and was not heard from again." This declaration was a surprising error for Macalpine and Hunter, whose scholarship is generally beyond reproach; in fact, in the 1820s, the ghost of increasing insanity was just beginning to walk the land [108, 109].

In contrast to the support he received, Burrows was also widely criticized by contemporary reviewers who did not agree with him. An anonymous reviewer in the 1821 Quarterly Review, for example, criticized Burrows's equating of suicide with insanity: "We question too the propriety of making the number of suicides an 
indication of the number of the insane, since we are not disciples of that creed which indiscriminately puts down every case of self-destruction to the score of deranged intellect." Burrows's second book on insanity was subjected to a scathing review in the same journal, where it was dismissed as "a mass of trash" and "a wretched compilation of scraps, gathered from all sorts of sources, and full of inaccuracies. . . The author, in truth, undertook a task to which his mind was totally unequal. . ." $[110,111]$

Burrow's claim that insanity was not increasing in England continued to be a minority view for the following four decades. A major reason for this was the publication by Sir Andrew Halliday of a Report of the Number of Lunatics and Idiots in England and Wales in 1829, 1 year after the publication of Burrow's second book. Halliday was an Edinburgh-trained physician who had participated in the 1807 census of the insane and then continued to collect data for the next 20 years. He had served as a physician in the Royal Navy, including being at the Battle of Waterloo when the Napoleonic forces were defeated, and had been knighted in 1821. He had also become the personal physician to William, duke of Clarence and St. Andrews, who in 1830 became King William IV. Halliday was regarded as one of the most knowledgeable professionals concerning the census of the insane and, since he was not connected to a public or private asylum, also one of the most credible.

In his report Halliday divided the insane into "lunatics" (developed insanity after childhood) and "idiots" (insane since birth) and counted separately those in asylums, those in workhouses, and those being kept at home. His preliminary count was 6,806 lunatics and 5,741 idiots, or 12,547 total, but he acknowledged that this was an undercount and estimated the true total at 16,500. Assuming the same proportion of lunatics to idiots in the uncounted portion of the total, the total number of lunatics in Halliday's estimate would have been 8,941 , or approximately 0.79 per 1,000 total population. This figure showed, Halliday concluded, that "insanity, in all its forms, prevails to a most alarming extent in England. . . . The numbers of the afflicted have become more than tripled during the last twenty years!" He added that it was no longer possible to dispute these "melancholy facts" and that it would be "a consciousness of criminal negligence were one to attempt longer to conceal them" [112].

Halliday also thought he knew why insanity was increasing. The cause, he said, was "over exertion of the mind, in overworking its instruments so as to weaken them ... the derangement of the vital functions, that re-act upon the brain, and derange its operation." He contrasted the large number of lunatics in England with their paucity among "the savage tribes of men; not one of our African travellers remark having seen a single madman" [113].

Over the next two decades, other physicians supported Halliday's conclusion. In 1835, for example, James C. Prichard published his Treatise on Insanity and Other Disorders Affecting the Mind in which he carefully assessed the data on insanity collected by the 1807 census as well as the work of Burrows and Halliday. Prichard was a Bristol physician who was widely respected for his 1813 book, Researches into the Physical History of Man, in which he speculated on the origin of the races and was among the first to suggest that humans had originated in Africa. After 
examining all of the evidence regarding increasing insanity, Prichard concluded that "the apparent increase is everywhere so striking that it leaves on the mind a strong suspicion that cases of insanity are far more numerous than formerly" [114].

In 1837 another prominent physician strongly supported Halliday's conclusion that madness was on the increase. William A.F. Browne, a Scottish physician, was a friend of Charles Darwin and author of What Asylums Were, Are and Ought to Be. According to sociologist Andrew Scull, Browne's book was "enormously influential" and made Browne "among the four or five most prominent British alienists of his generation." Regarding insanity, Browne claimed "that a much greater number of cases is known to exist, and to require treatment, than formerly," and that the increase was far more rapid than the population in general. The reason for this increase, according to Browne, was that "as we recede, step by step, from the simple...manners of our ancestors, and advance in industry and knowledge and happiness, this malignant persecutor strides onward, signalizing every era...by an increase, a new hecatomb, of victims" [115].

In 1843 the first census of insane persons was carried out since Halliday's report in 1829. It found 14,792 "lunatics" in public and private asylums, workhouses, and private dwellings. Based on the total population of England, the rate of insanity was thus 0.93 per 1,000 people. In 1829 Halliday had reported a total of 8,941 insane persons, or 0.79 per 1,000 population. Thus during the 14 years, there had been an 18 percent increase in insanity, supporting the claims of Halliday, Prichard, Browne, and others.

One of the interesting findings from the 1843 census was that insanity in England was not evenly distributed. Nine counties in Southern England and the Midlands (Gloucestershire, Oxfordshire, Berkshire, Wiltshire, Hampshire, Dorset, Somerset, Devonshire, and Cornwall) had a rate of insane persons per 1,000 total population of 0.46 to 0.89 , with an average of 0.65 . Three of these counties (Wiltshire 0.89, Hampshire 0.84, and Dorset 0.76) were among the four English counties with the highest rates of insanity and are contiguous. The eight northernmost counties, by contrast, had a rate of insane persons per 1,000 total population of 0.29 to 0.52 , with an average of 0.42 . These included the four counties with the lowest rates (Lancashire 0.38, Cheshire 0.33, Staffordshire 0.39, and Derbyshire 0.29) and are also contiguous. Thus, insanity in England in 1843 appeared to be most prevalent in the south and the Midlands and to become less prevalent as one moved north. It was a pattern that would be seen repeatedly later in the century [116].

In addition to the 1843 census, there were other indications that insanity was increasing at this time. The number of private insane asylums had increased from 72 in 1815 to 149 in 1849, and the size of many of them had doubled or more. The first eight public asylums, opened by 1823, had an average of 116 beds, "but almost at once it became clear that the number of beds needed had been seriously underestimated in most areas, and the asylums grew rapidly in size." For example, the asylum at Lancashire was built in 1816 for 250 patients, but by 1844 it held 600 . The Nottinghamshire Asylum increased from 80 to 206 beds, and the Bedfordshire Asylum nearly quadrupled in size from 40 to 139 beds between 1812 and 1844 . Additional asylums were built, including the Middlesex Asylum at Hanwell, with 
1,000 beds to serve London, but they were filled as soon as the doors were opened [117].

It should be noted that the increase in asylum population in the second quarter of the nineteenth century occurred despite high death rates in the asylums. At the Lancashire Asylum, cholera killed 94 patients in 1832, and influenza killed 46 more in 1837. At the Wakefield Asylum, influenza killed 30 in 1837, and cholera killed over 100 in 1849. The death rate for new admissions to the Hanwell Asylum was 18 percent in the first year, reflecting the fact that many admissions also had serious medical, as well as psychiatric, problems [118].

Still another measure of the increasing insanity was the number of forensic cases, called criminal lunatics, being held in asylums. In 1837 they totaled 138 for all of England but by 1847 they had increased to 337. Such numbers surprised nobody since people had been observing an increasing number of high-profile, violent acts by insane person. In 1812, for example, John Bellingham, paranoid and insane, had shot Prime Minister Spencer Percival in the lobby of the House of Commons. In 1829 an insane Jonathan Martin had set fire to the York Cathedral. In 1840 Edward Oxford shot at Queen Victoria's carriage and was subsequently declared insane. Three years later, Daniel M'Naghten shot Edward Drummond, mistaking him for Prime Minister Robert Peel. Indeed, according to one historian of this period, "it would be safe to say that a majority feared that madness was spreading in epidemic proportions from man to man, from generation to generation, and from region to region. Many saw madness as a monster lying beneath the surface, waiting to be given an opportunity to rise and consume their England" $[119,120]$.

As noted previously, there was considerable local resistance to the building of public asylums in England. In later years some historians, such as Michael Foucoult in Madness and Civilization, would argue that asylums were built as part of "the great confinement" of the insane, paupers, criminals, and vagrants who were not economically productive. The financing of asylums was, until 1874, the exclusive responsibility of local governments, which meant higher local taxes each time an asylum was built; after 1874 the central government contributed approximately 40 percent of the asylum costs.

Given such costs, it is not surprising that "ratepayer and taxpayer resistance to increased public expenditure was deep-rooted, vituperative, and often crippling." As early as 1859, the persistent calls by public officials to build new asylums and enlarge existing asylums were said to cause "terrible discouragement and complaint with the ratepayers." In Sussex "there was clearly a highly organized campaign against building a county asylum." In Buckinghamshire in 1849, "six hundred ratepayers, led by Benjamin Disraeli, renewed their opposition [to an asylum], complaining that they had already been taxed for a new jail and judges' lodging, and were now being asked to underwrite another expensive capital project." Disraeli was at the time a member of parliament for Buckinghamshire. An editorial in the Westminster Review complained of pianos and other "lavish expenditures" in public asylums: "It is no exaggeration to say that two-thirds of the permanent residents in every pauper asylum care little for the luxurious furnishings around them. A 
considerable proportion, indeed, could not tell the difference between a palace and a stable-yard" [121-127].

A large number of skirmishes in the battle over the costs of insanity took place regarding local workhouses. It was these institutions that had housed mentally ill individuals before the county asylums were built, and they did so at a cost of one half to one eighth the cost of asylum care. When county authorities were ordered to transfer mentally ill residents from the workhouses to the newly built asylums, they often transferred only the most disturbed and disturbing individuals and kept the rest in the workhouses. In 1828, for example, there were estimated to be approximately 9,000 "lunatics and idiots" in England's workhouses. This number decreased in the 1840 s and early 1850 s as more county asylums opened but then increased again by 1861 to almost 9,000, and by 1870 "workhouses held over 12,000 pauper lunatics, about 25 percent of their total number.” By this time some county asylums, faced with marked overcrowding, were even quietly transferring some chronic and nonassaultive patients back to workhouses despite laws and official psychiatric rhetoric prohibiting such transfers [128-131].

In the 1850 s, insanity increased faster than it had ever done. A national census carried out in 1854 reported a total of 30,538 insane persons, more than double the 14,792 reported in 1843 . At the next census in 1859 , the number had risen to 36,762 . Even allowing for population growth insanity had doubled in 15 years from 0.93 per 1,000 population to 1.87 per 1000 . Especially alarming was the suspicion that the insanity was disproportionately affecting "the better sort." According to Andrew Scull, "the best professional opinion suggested that it was the educated, the wealthy, the most cultural segments of the community...who had the most to fear from the spectre of madness" [132].

Many medical professionals continued to express concern. In 1848, in his book Insanity Tested by Science, Charles M. Burnett observed: "It has long been a popular opinion that insanity is a more common disease in our country than in any other, and that this opinion has of late years been strengthened by the assertion of many that the disease is on the increase." Two years later an author, identified only as "the late Medical Superintendent of an Asylum for the Insane," described insanity as "a great national evil, spreading through numerous families, in which every remedy that medical science can suggest, and law can enforce, ought immediately to be applied." In 1854 Alfred Maddox, the proprietor of an asylum in Kent, claimed that "in no other country, compared with England, do we find such numerous and formidable examples of this extensive scourge." And 3 years later, John Hawkes, a medical officer in the Wiltshire County Asylum, wrote that "the fair face of England, dotted over with her many public asylums for the relief and refuge of mental disease, presents a picture of rare and painful interest. . . . I doubt if ever the history of the world, or the experience of past ages, could show a larger amount of insanity than that of the present day" [133-136].

It was not only medical men who were alarmed by the rising insanity but the general public as well. Gossip and newspaper accounts of mad persons became commonplace, as one account in The Times describing the "Conduct of a Lunatic in 
a Church," in which a man "got into the pulpit just as the clergyman was coming from the vestry to read his sermon... The man clung to the gas fittings and was not removed until after a desperate struggle with the sexton and his assistants." Such public accounts often included serious misdeeds, including one under a headline of "Horrible Circumstance," in which a "maniac" named Big Hector "lately visited Edderton, in the eastern portion of this county, where, having taken hold of a child (a girl), he ate the flesh off her arm, and the poor sufferer when relieved was, and still is, in a very painful and dangerous condition." By the end of the 1850 s, one journal lamented "such a period as the present, when lunacy and lunatic affairs claim so large an amount of attention and interest on the part of the general public" [137-139].

In response to the rising alarm among the general public about the conditions of the asylums and the steadily increasing number of mad people, parliament in 1859 appointed yet another Select Committee on lunatics to investigate the situation. Testimony before the committee included a description of an asylum at London's Colney Hatch, which had opened in 1851 with accommodations for 1,220 "lunatic poor" but which "almost immediately ... was filled with a mass of chronic patients." "And now," the testimony continued, "within a period of five years, it has again become necessary to appeal to the county to provide further accommodation for its pauper lunatics" [140].

\subsection{Official Denial of the Problem}

From 1859 onward the official position of the British government, as represented by the Lunacy Commission, was that insanity was not increasing. The "apparent" increases were said to be due to improved case finding and the accumulation of chronic cases in the asylums. Once established, this official position never changed. Year after year the Lunacy Commission's annual report listed increases in the number of insane persons in England, followed immediately by ritual assurances that the increases were only "apparent" due to an "accumulation" of cases.

The government's efforts to persuade the public that insanity was not increasing were helped immensely by England's psychiatric establishment. In 1841, physicians working in the asylums had organized the Association of Medical Officers of Asylums and Hospitals for the Insane, which later became the Medico-Psychological Association and eventually the Royal College of Psychiatrists. In 1853 this organization began publishing the Journal of Mental Science, later to become the British Journal of Psychiatry, regarded as the official voice of English psychiatry. From the beginning of its publication until 1895, the Journal of Mental Science was edited or coedited by four psychiatrists—John Bucknill, C. Lockhart Robertson, Henry Maudsley, and Hack Tuke - all of whom aggressively promoted the idea that insanity was not increasing. Thus, the official government position and the official psychiatric position reinforced and supported each other, and no matter how alarming the reported increases of insane persons, the increases were invariably labeled as being merely "apparent." 
John Bucknill was superintendent of the Devonshire Asylum from 1844 to 1862 . In 1853 he became the first editor of the Journal of Mental Science and later became president of the Medico-Psychological Association and was knighted. In an 1858 textbook written with Hack Tuke, he said:

\begin{abstract}
"On no subject has there been more absurd and illogical reasoning, or more hasty generalisations, than on the proportion of the insane to the population. . . . Highly important inferences are drawn with the utmost complacency, and apparently in entire ignorance of the fallacy which underlies such loose and worthless calculations.... In our own country there are two reasons why the proportion of the insane to the population appears to be greater than was formerly the case. The first is, that the disease is recognised as such to a far greater extent than formerly; and the second is, that we know, to a much greater extent than heretofore, the number of the insane throughout the country. In the short period of nineteen years, the estimated proportion of the insane in England rose from 1 in 7,300 to 1 in 769; a difference which led to the belief in the frightful increase of insanity, but which by no means warranted such a conclusion. The knowledge of an evil, and the existence of that evil, are two widely different things."
\end{abstract}

Bucknill also agreed with Lord Shaftesbury that if any portion of the "apparent" increase in insanity was real, that portion was probably attributable to "intemperance" and "the over-tasking of emotions" caused by advancing civilization [141].

In 1862 C. Lockhart Robertson assumed editorship of the Journal of Mental Science. Robertson was superintendent of the Sussex County Asylum from 1859 to 1870 and a president of the Medico-Psychological Association, and he labeled the increase of insanity in England as "a manifest fallacy." In 1869 he published a widely cited article entitled "The Alleged Increase of Lunacy," in which he acknowledged that there had been "an increase in the last twenty-five years in the number of registered lunatics of more than a hundred per cent," but he claimed that this was caused by better case finding, better statistics, and the accumulation of chronic cases in the asylums. He admitted that admissions to the asylums were still continuing to rise but said that this was no cause for concern since "the rate of increase is in a yearly decreasing ratio." He concluded that "the alleged increase of lunacy is a popular fallacy, unsupported by recent statistics" [142].

Robertson used the Journal of Mental Science as a forum to vigorously publicize his position. Summaries of his article "The Alleged Increase of Lunacy" were also published in popular periodicals, including The Pall Mall Gazette, the Saturday Review, and the North British Review, and Robertson dutifully reprinted these summaries in the Journal of Mental Science. In an 1871 issue, Robertson included a "Report on Insanity in Wiltshire," in which the author concluded that "the supposed increased liability to insanity in England at the present time, as compared with the earlier part of the century, may to a great extent, or even altogether, be imaginary, when the increase in the general population is considered." At the same time, Robertson continually reminded readers of the great advances being made by modern psychiatric treatments. In view of these advances, an increase in insanity was, in Robertson's view, a “terrible possibility which I entirely dispute” [143-145].

Following the 1859 Select Committee hearings, it became apparent that there still was much public concern about the rising insanity. According to Andrew Scull, 
"The progressive increase in insanity was obvious to those with only the most casual acquaintance with the subject...Public fear of the legions of crazy men and women that society was apparently spawning at times verged on panic." To allay such fears, the Lunacy Commission increased the frequency of the census of insane persons to annually. The result reassured nobody. Year after year the result was more insane persons than the year before. Over the next 12 years, from 1860 to 1871, the total number of insane persons increased from 36,762 to 56,755 , a 54 percent increase. When considering the growth of the general population, the increase was still a 33 percent increase, from 1.87 insane persons per 1,000 population to 2.49 per 1,000 . Including the growth of population, there were three times more insane people in England in 1871 than there had been in 1829 [146].

Each year the new figures were announced, followed by predictable reassurances by the psychiatric establishment that the increase was only "apparent." The new cases had been there all along, they argued, and the ability to identify and count them had improved. The increase was thus merely a statistical artifact, nothing to worry about.

Most people were not reassured. In 1864 The Times noted: "Our asylums, private and public, now contain nearly twice as many patients as they did 15 years ago. ... But this large number does not fully represent the total amount of insanity existing in the country; there are also the insane in gaols, the Chancery patients living out of asylums, and cases kept out of view for private or other reasons." In 1868 The Times reported that in the previous 10 years insane persons had increased " 45 percent while the population is estimated to have increased rather more than 11 percent." The following year the North British Review, examining the statistics on insanity, concluded: "If we examine the effect of this at the end of a long series of years, we have a result which cannot fail to startle." And a few years later, The Times quoted a magistrate as saying that "if the lunacy continued to increase as at present, the insane would be in the majority and, freeing themselves, would put the sane in the asylums" [147, 148].

In 1870, Henry Maudsley followed doctors Bucknill and Robertson as the editor of the Journal of Mental Science. Although only 35 years old, he had already published a widely read textbook on The Physiology and Pathology of the Mind, had been nominated as president of the Medico-Psychological Association, and "had established himself by most measures as the dominant voice in the [psychiatric] profession." The fact that he had married the daughter of John Conolly, the most influential psychiatrist of the mid-nineteenth century, also was useful for Maudsley's career prospects. Although in later years Maudsley would distance himself from his psychiatric colleagues, in 1870, he was most interested in promoting his profession and himself [149].

It was at this time that Maudsley published the first of two articles in which he hoped to definitively discredit the idea that insanity was increasing. He argued that the claim "that so many more persons should be yearly going mad now than twentyfive years ago, seem to me a superstition which is, I will not say preposterous, but is certainly not probable in itself and not supported by facts." Using his considerable analytic and writing skills, Maudsley suggested four reasons why insanity only appeared to be increasing [150].

The first reason was the one that had been invoked by other critics of increasing insanity for many years - the closet theory. That is, that England had always had 
this number of insane persons, but they were "kept at home, or farmed out to their relatives, or taken care of in some other way of which there was no official knowledge." It was only when the asylums were built, claimed Maudsley, that these people appeared. The major problem with this argument was determining cause and effect: did the building of asylums bring existing insane persons out of the closet or did increasing insane persons appear thereby creating the need to build more asylums? And assuming that there was at least some truth to the closet theory, is it reasonable to expect this backlog of cases to continue appearing for half a century? Wouldn't you expect that at some point all the closets would have been emptied? In fact, Maudsley discussed this issue and predicted that all the old cases would be taken care of by 1883. As will become evident, that did not happen [151].

The second reason cited by Maudsley for why insanity was not really increasing was a broadening of the diagnostic categories. As he phrased it, "certain patients were registered as lunatics then who...would not have been classed as lunatics a quarter of a century before." Maudsley offered no supporting data, and in fact the reports of the Lunacy Commission contradicted him. For the last half of the nineteenth century, the diagnoses of patients were remarkably consistent; most of them were labeled with mania, melancholy, and dementia and a smaller number with general paralysis of the insane (brain syphilis), epileptic psychosis, and alcoholic insanity. Some asylum superintendents also contradicted Maudsley. The head of the Staffordshire Asylum, for example, said that his admission statistics "do not lend support to the idea which one hears expressed from time to time that many people are sent to asylums who have no business there. Such is certainly not our experience; on the contrary, we find that patients are frequently not brought here until it is impossible to keep them outside" [151, 152].

In more recent years, the question of broadened diagnostic categories as an explanation for the increasing insanity in England has been examined systematically. Psychiatric records from nineteenth-century asylums have been rediagnosed using modern diagnostic criteria. For example, a comparison of all admissions to Lancashire's Rainhill Asylum in 1890 and 1990, using the International Classification of Diseases (ICD 9), reported the following diagnostic breakdown:

\begin{tabular}{|l|l|l|}
\hline $\begin{array}{l}\text { Psychoses (schizophrenia, manic-depressive illness, psychotic } \\
\text { depression, hypomania, manic episode) }\end{array}$ & $\begin{array}{l}1890 \\
\text { admissions }\end{array}$ & $\begin{array}{l}1990 \\
\text { admissions }\end{array}$ \\
\hline $\begin{array}{l}\text { Depression } \\
\text { Drug-induced psychosis }\end{array}$ & $18 \%$ & $24 \%$ \\
\hline $\begin{array}{l}\text { Alcohol-related illness } \\
\text { Dementia (Alzheimer's and other) }\end{array}$ & $0 \%$ & $2 \%$ \\
\hline Epilepsy & $8 \%$ & $16 \%$ \\
\hline General paralysis of the insane & $6 \%$ & $1 \%$ \\
\hline Mental subnormality & $6 \%$ & $0 \%$ \\
\hline Acute confusional state & $11 \%$ & $0 \%$ \\
\hline Anxiety-related illness & $11 \%$ & $0 \%$ \\
\hline Personality disorder & $3 \%$ & $2 \%$ \\
\hline No mental illness & $0 \%$ & $5 \%$ \\
\hline
\end{tabular}


Such results lend no support to the belief that patients admitted in 1890 were mild cases. These findings are also consistent with retrospective diagnostic studies of patients from nineteenth-century private asylums, including Trevor Turner's study of Ticehurst Asylum, Edward Renvoize and Allan Beveridge's study of the York Retreat, Franklin Klaf and John Hamilton's study of Bethlem Hospital, and William Parry-Jones's study of Duddeston Hall and Brislington House [153-157].

A "lower percentage of recoveries" was the third reason listed by Maudsley to explain the apparent increase in insanity. There is some evidence to support the fact that recovery rates for hospitalized persons decreased in the second half of the nineteenth century, including studies of the asylums at Lancashire, Buckinghamshire, Colney Hatch, and Hook Norton. Such findings were cited in 1890 as evidence that "the form of insanity was worse" than it had been earlier in the century. These findings are consistent with Robert Wilkins's findings of an increasing number of young patients admitted to Bethlem with symptoms of auditory and visual hallucinations between 1830 and 1899. It is also consistent with Hack Tuke's 1892 observation that "a large number of cases of pubescent and adolescent insanity terminate more unfavorably than the mental physician, guided in his prognosis by the general truth, has been led to expect." Such patients would now be diagnosed as having schizophrenia. It should also be noted that insofar as more severe cases were being seen with fewer recoveries as the nineteenth century progressed, this directly contradicts the claim that less severe cases were being hospitalized during those years $[158,159]$.

Finally, Maudsley argued that there was an apparent increase in insanity because insane persons were living longer "in well-conducted asylums where they are well fed, well clothed, and well housed." As evidence he cited three asylums in which patients were well fed as having a lower annual mortality rate compared to four asylums in which patients were not as well fed with higher mortality rates. In fact, however, asylum death rates varied widely by year and by asylum. Infectious diseases such as typhus, cholera, pneumonia, tuberculosis, and syphilis were the most common causes of death in the asylums, followed by cardiovascular diseases. Given the actual conditions of most of the public asylums, it is likely that insane persons who entered asylums lived shorter lives, not longer lives, than if they had remained living in the community. This possibility had been suggested as early as 1835 by William Farr who calculated that death rates in asylums were three to six times greater than that of the general population at comparable age levels, and these figures were confirmed in 1879. For patients ages 20 to 24, the Lunacy Commission reported in 1906 that "the insane death-rate is nearly twenty times that of the general death-rate." However, given the epidemics of infectious diseases that frequently devastated the overcrowded asylums (e.g., cholera in 1832-1833 killed up to 49 percent of the asylum inmates), one can argue that increasing institutionalization of insane persons in the nineteenth century may have ultimately decreased their total number by killing larger numbers than would have died had they been living in the community. Thus by increasing the death rate of insane persons, the asylums may have decreased the rate of rising insanity, not increased it as Maudsley claimed [160-162]. 
By the late 1870s, Henry Maudsley "had established himself as the preeminent figure among British alienists" and he remained so until his death in 1918. Since Maudsley had said that the increasing insanity was not real but only apparent, that would be the official position of the psychiatrists. Hack Tuke, who followed Maudsley as the editor of Journal of Mental Science from 1880 until 1895, illustrated this position. Andrew Scull has labeled Tuke "the most unembarrassed apologist for Victorian asylumdom." William Bynum characterized Tuke as "a good 'party' man, devoted to improving the status of his profession in Britain." For example, in his Chapters in the History of the Insane in the British Isles, Tuke claimed "remarkable progress effected in the asylum care of our lunacy population." Although early in his career Tuke had expressed uncertainty about whether insanity was increasing or not, he later concluded that "the increase of insanity is apparent rather than real, being mainly due to accumulation" [163-167].

Tuke wrote extensively about the alleged increase of insanity and analyzed the available statistics from the Lunacy Commission to try to prove his point. He advocated the use of first admissions, rather than the total patients hospitalized, as "the only sound test of the increase of insanity." For example, in 1882, he recorded the first admissions per 10,000 total population for 12 years as follows:

\begin{tabular}{ll|ll}
1869 & 4.71 & 1875 & 5.19 \\
1870 & 4.54 & 1876 & 5.30 \\
1871 & 4.62 & 1877 & 5.28 \\
1872 & 4.59 & 1878 & 5.36 \\
1873 & 4.80 & 1879 & 5.20 \\
1874 & 5.03 & 1880 & 5.19
\end{tabular}

His conclusion was that "the ratio of the yearly increase of the fresh admissions to the population has been slight," when in fact the increase was 10 percent over the 12-year period. By 1894 first admissions per population had increased another 10 percent; Tuke dismissed the figures, saying: "I have now reason to believe that the returns which have been since published [since 1880] cannot be trusted" [168].

For a "good 'party' man" like Hack Tuke, increasing insanity was simply unacceptable, as it had been for Bucknill, Robertson, and Maudsley before him. Tuke labeled the idea that insanity was increasing "a melancholy theory" that "would unsettle our belief in the onward progress of mankind, it would shake the very foundation of our faith." Increasing insanity would imply not only that the asylums had failed but also that the psychiatrists themselves had failed. It was an unacceptable possibility. As Mr. Podsnap said in Dickens's Our Mutual Friend, "I don't want to know about it; I don't want to discuss it; I don't want to admit it!" [169, 170]

Despite the assurances that improvement in asylum conditions had been "well nigh incredible" and Hack Tuke's claims of "remarkable progress," the continuing influx of insane individuals in the closing years of the nineteenth century overwhelmed the asylums. In 1824 there had been only eight public asylums with an average size of 116 beds. By 1860 there were 41 asylums with an average of 386 beds and, by 1890, 66 asylums with an average of 802 beds. Each annual report of the Lunacy Commission reported new asylums under construction, new wings 
being added to existing asylums, and the conversion of "several houses on the estate lately occupied by attendants . . . being prepared for the reception of patients." The West Riding Asylum had opened in 1818 with 150 beds; by the end of the century, it had 1,469 beds, almost a tenfold increase. As early as 1856, John Bucknill, superintendent of the badly overcrowded Devonshire Asylum, boarded out "quiet, chronic, female patients in neighboring cottages beyond the asylum grounds" and rented "a house in the nearby seaside town of Exmouth, where he boarded forty to forty-five quiet female patients under the care of a resident medical officer . . . and two resident female nurses," harbingers of deinstitutionalization, which would come a century later [171-173].

\subsection{The Debate Winds Down}

Despite the constant assurances by some of the leaders of English psychiatry that insanity was not really increasing, most people, including most psychiatrists, believed that it was. James Crichton-Browne, superintendent of the Yorkshire West Riding Asylum, wrote: "It is impossible for us to acquiesce in the soothing doctrine now being disseminated that the alleged increase of lunacy is only a popular fallacy"; rather, he said, it was clear "that an actual as well as an apparent augmentation in the numbers of our insane poor is rapidly in progress." In a similar vein, Martin Duncan said that it was time "to admit that for once popular fallacy is supported by recent statistics. ... There is a steady increase in the lunacy of the population of England, Wales, and Ireland. . . . Insanity remains as a dead-weight on the statistics of our social miseries." John Arlidge noted that "the increase of lunacy . . . [is] a painful and perplexing fact" and that available data "indisputably [point] to an absolutely increased production in the community." Harrington Tuke, not related to Hack Tuke, also claimed that "these figures would appear to prove that a great wave of insanity is slowly advancing, but making each year a definite progress." And Robert Jamieson of the Royal Aberdeen Hospital claimed that "the most remarkable phenomenon of our time has been the alarming increase of insanity" [174-176].

As the century drew to a close, the leadership of English psychiatry decided to try once again to counter the public alarm about rising insanity by holding a "special enquiry into the alleged increase of insanity in England and Wales" under the commissioners in lunacy. Because the commissioners had had primary responsibility for the problem of insanity since 1845 and had stated many times that insanity was not increasing, the outcome of the enquiry was a foregone conclusion.

The resulting "Special Report on the Alleged Increase of Insanity" was published in 1897. Large portions appear to have been adapted from an 1890 study by Noel Humphreys, a statistician, who had concluded:

Without therefore venturing to say that there has been no increase of insanity in England in recent years, many reasons have been pointed out for refusing to accept any insanity statistics that we at present possess as conclusive evidence of a real increase of the rate of occurring insanity. 
Humphreys' cautious conclusions were eagerly enlarged upon by some psychiatrists. George Savage said they put to rest "one of the bugbears of the age, the idea that insanity was running like wildfire through the whole population." Hack Tuke also "rejoiced to find the conclusions at which Mr. Humphreys had arrived were so much in accordance with what might be regarded as an encouraging and satisfactory mode of viewing the great question of the alleged increase of insanity in England and Wales" [177].

The 1897 Special Report included data on the increase in asylum patients between 1859 and 1896. Especially damning was a table showing that first admissions had increased from 4.71 per 10,000 total population in 1869 to 5.16 in 1879 , 5.29 in 1889, and 6.09 in 1895 . The report acknowledged that "the upward progress ... of first attacks out of proportion to population seems prima facie to indicate the increase of insanity which has been alleged, and we must now inquire if there are any circumstances which modify its apparently significant influence" [178].

The bulk of the 1897 Special Report then examined in great detail the same reasons why insanity was not increasing that had been invoked by Henry Maudsley in the 1870s. First, most insane persons had been kept at home and only became recognized when the asylums were built. Second, the diagnostic category of insanity had been broadened, thus bringing less severely ill individuals to the asylums. Third, over the course of the nineteenth century, fewer patients were recovering, thus decreasing discharges and increasing the census. And, finally, insane persons were living longer in the asylums than they would have if they had remained at home.

In fact, the data cited by the 1897 Special Report was no more convincing than it had been 20 years earlier when offered by Maudsley. The only explanation for which there was evidence-that insanity was clinically becoming more severe in the nineteenth century - was hardly one that would have reassured the press or the public regarding their fears of rising insanity. The commissioners concluded their report by stating that "we have been unable to satisfy ourselves that there has been any important increase of occurring or fresh insanity." Given their own data, such a conclusion was wishful thinking.

Five months following the publication of the 1897 Special Report, the commissioners in lunacy issued their annual report for 1897, showing a total of 99,365 insane persons, an increase of 2,919 since the previous year, the increase being "the largest on record." The following year, the total increased by an additional 2,607 patients to 101,972 , which the commissioners labeled "this huge mass of insane humanity." The figures appeared to be an additional refutation of their 1897 report [179, 180].

Nor was the English press convinced by the 1897 Special Report. The Westminster Review labeled it "ridiculous efforts to gloss over and explain away undeniable facts. . . That there is an actual increase is indubitable, notwithstanding the dogmatic but puerile asseverations of the Commissioners in Lunacy to the contrary. . . Were the Commissioners in Lunacy cross-examined on their own figures and the inferences they have drawn, a lamentable appearance might be predicted" [181].

The most damning criticism of the English Lunacy Commission, however, came from W. J. Corbet, the chief clerk of the Irish Lunacy Department and a former 
member of parliament from Ireland. He said the authors of the special report had "devoted all their energies to combating the idea that insanity is on the increase. . . a more remarkable composition has rarely, if ever, emanated from official brain or pen." Not a man to hide his opinions, Corbet had previously accused the commissioners of "fossilized officialism" as well as "Lilliputian logic" and had compared them to "simple parents fondling their deformed offspring . . . hugging the fallacy they have themselves created, until, by constant repetition, they at length evidently believe in the soundness of their conclusions, though the figures given in their own reports are convincing to the contrary" [182].

Following the publication of the 1897 Special Report, public discussion of increasing insanity in England continued for another decade, as the number of institutionalized insane increased from 101,972 (3.24 per 1,000) in 1898 to 126,084 (3.60 per 1,000) in 1908. Newspapers continued to express concern about "the grave increase of lunacy. . . Assuming a similar increase in the future, what is the outlook for, say, 50 years hence?" And the psychiatric establishment continued to offer a multitude of reasons to explain why the increase was not real but merely apparent, as in this 1903 report: "The question that at once presents itself is whether this growing ratio means that insanity on the whole is increasing. There are several other explanations which would require to be borne in mind before admitting such an unpleasant one" [183].

It is important to understand how dissonant the idea of rising insanity was at the end of the Victorian era. England had become the dominant world power. It had assumed, in Kipling's phrase, "the white man's burden" and had overrun, annexed, or purchased one quarter of the earth's land surface. England controlled territory from the Transvaal to Cyprus and Uganda to Fiji, had purchased the Suez Canal, and had proclaimed Queen Victoria as the Empress of India. By 1892 "Britain had more registered shipping tonnage than the rest of the world put together." At home, "the horsepower used in British industry increased from two million in 1870 to ten million in 1907." Benjamin Disraeli described England as having undergone a "convulsion of prosperity." However, amid this prosperity, the number of insane persons had risen from 8,941 in 1829 to 126,084 in 1908, more than quadrupling the number even when the increase in population was taken into account. Worse yet, visitors from France, America, and other countries had publicly commented on the problem. Insanity was an uninvited and most unwelcome guest at England's celebratory banquet. A solution to the problem would come from unexpected events [184].

Even the psychiatrists were trying to solve the problem of increasing insanity; political events were taking place in Europe that would soon focus England's attention on other problems. In Hamburg the kaiser asserted Germany's "place in the sun" and renewed his nation's alliance with Austria and Italy. The Balkan Wars spread unrest progressively across Europe. Finally, on June 28, 1914, Archduke Franz Ferdinand, heir to the Austrian throne, was assassinated in Sarajevo, and within weeks, Europe was at war.

World War I substantially altered the perception of insanity in England, reducing it from a growing threat to merely an ongoing inconvenience. Insanity was no longer viewed as an increasing affliction of the body politic, evoking letters in The 
Times, but instead as a chronic blemish on the human condition for which little could be done. The pervasive nineteenth-century fear that insanity was increasing was largely eclipsed by current events.

In 1914, when the war began, there were 138,055 insane persons in 97 English asylums. By January, 1915, the number had climbed to 140,466 , or a rate of 3.98 per 1,000 total population. This contrasts with the first reliable national census in 1829 which counted 8,941 insane persons or 0.79 per 1,000 population (Fig. 5.3). Over the 86-year period, between 1829 and 1915, there was therefore a fivefold increase in the number of insane persons per population. One out of every 250 persons of all ages was confined to an insane asylum, and among young adults, the rate was much higher.

World War I had a direct effect on the asylums because hospitals were needed to treat large number of war casualties. Therefore, the government "took over a number of county asylums, and other asylums had to accept and house their displaced patients for the duration of the war." Insane patients who were less severely disabled were sent home, many new admissions were refused, and in the remaining asylums "extra beds were squeezed into the dormitories, the corridors [were] filled with beds, [and] other rooms were converted into bedrooms." In addition, almost half of the medical and nursing staff went off to fight, and food rations for the mental hospitals were reduced [185].

Then, at the height of this crowding, understaffing, and reduced food rations, the influenza pandemic arrived. The death rate among patients soared, as can be seen from the deaths in the Buckinghamshire Asylum:

\begin{tabular}{|l|l|}
\hline 1910-1914: & 67 \\
\hline 1915: & 81 \\
\hline 1916: & 110 \\
\hline 1917: & 129 \\
\hline 1918: & 257 \\
\hline
\end{tabular}

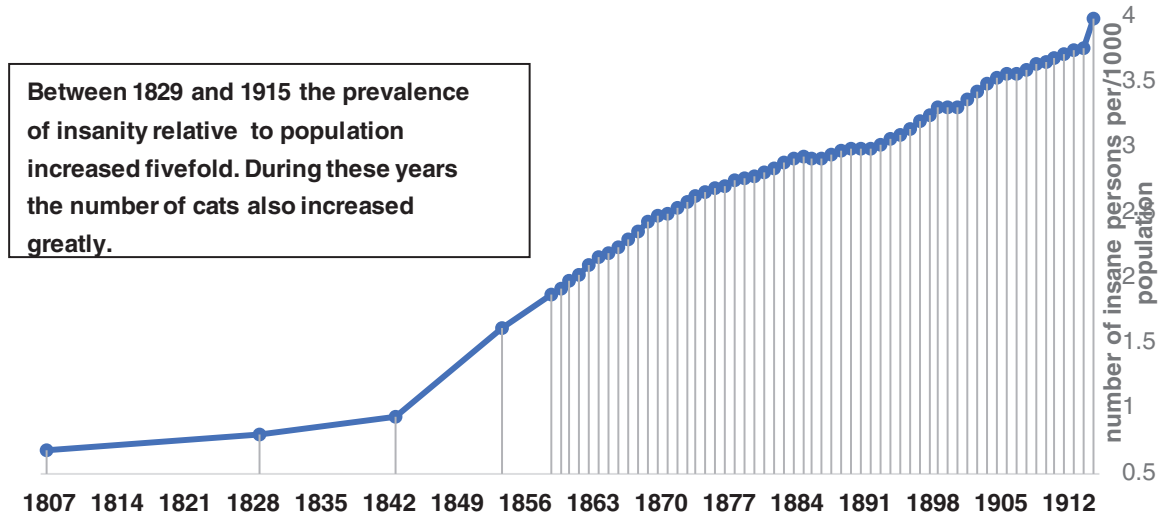

Fig. 5.3 Number of insane persons per 1,000 population, England and Wales. (Source of data: E. Fuller Torrey and Judy Miller, The Invisible Plague. Table 1. pages 345-346.) 
In 1918, almost one third of all the patients died in this asylum. Nationally, the total number of 1918 asylum deaths was 19,515, double the prewar rate. By 1920, then, the census of England's mental hospitals had been reduced 17 percent to 116,764 . After a century of looking for a solution to the increasing insanity, two had finally emerged-war and influenza [186].

\section{References}

1. Macalpine I, Hunter R. George III and the mad business. London: Pimlico; 1991. p. 291.

2. Tague, IH. Animal companions: Pets and social change in 18th century Britain. University Park Pennsylvania: Pennsylvania State University Press; 2015. p. 2.

3. Ritvo H. The animal estate. Cambridge: Harvard University Press; 1987. p. 86.

4. Keenan S. Animals in the house. New York: Scholastic; 2007. p. 30.

5. Rogers, KM. Cat. London: Reaktion Books; 2006. p. 47.

6. Amato S. Beastly possessions. Toronto: University of Toronto Press; 2015. p. 29.

7. Vocelle LA. Revered and reviled: a complete history of the domestic cat. Great Cat Publications, 2016. [no city listed]. p. 262.

8. Murfin L. Popular leisure in the lake counties. Manchester: Manchester University Press; 1990. p. 14.

9. Rush W. Thoughts on insanity. Knick. 1836;7:33-6.

10. Amato S. Beastly possessions. Toronto: University of Toronto Press; 2015. p. 63.

11. Entry for Robert Southey on Wikipedia.

12. Winslow HM, Concerning cats. Boston; Lothrop Publishing, 1900. p. 112.

13. Winslow HM, Concerning cats. Boston: Lothrop Publishing; 1900. p. 112.

14. Jamison KR, Touched with fire: Manic-depressive illness and the artistic temperment. New York: Free Press; 1993. p. 169.

15. Rogers, KM. Cat. London: Reaktion Books; 2006. p. 62.

16. Vocelle LA. Revered and reviled: a complete history of the domestic cat. Great Cat Publications, 2016. [no city listed]. p. 289.

17. Ackroyd P. Blake. London: Vintage; 1995. p. 235.

18. Rogers, KM. Cat. London: Reaktion Books; 2006. p. 94.

19. Vocelle LA. Revered and reviled: a complete history of the domestic cat. Great Cat Publications, 2016. [no city listed]. p. 309.

20. Rogers, KM. Cat. London: Reaktion Books; 2006. p. 90, 63.

21. Ritvo H. The animal estate. Cambridge: Harvard University Press; 1987. p. 129.

22. Winslow HM, Concerning cats. Boston: Lothrop Publishing; 1900. p. 128,114.

23. Vocelle LA. Revered and reviled: a complete history of the domestic cat. Great Cat Publications, 2016. [no city listed], 315.

24. Anonymous, "The cat about town," Living age 217: 47-49, April-June 1898.

25. Champfleury M. The cat past and present. London: George Bell; 1885. p. 64.

26. Winslow HM, Concerning cats. Boston: Lothrop Publishing; 1900. p. 119-120.

27. Amato S. Beastly possessions. Toronto: University of Toronto Press; 2015. p. 10.

28. Lynnlee JL. Purrfection the cat. West Chester: Schiffer Publishing; 1990. p. 25-6.

29. Champfleury M. The cat past and present. London: George Bell; 1885. p. 22.

30. Champfleury M. The cat past and present. London: George Bell; 1885. p. 75.

31. Bugler, C. The Cat: 3,500 years of the cat in art. New York: Merrell; 2011. p. 248.

32. Pargeter W. Observations on maniacal disorders. London: Routledge; 1988. p. 1-3. Originally published in 1792

33. Leigh D. The historical development of British Psychiatry. Vol I. Oxford: Pergamon; 1961. p. 144.

34. Haslam J. Observations on insanity. London: F. and C. Rivington; 1798, Preface, iii. 
35. Persaud RD. A comparison of symptoms recorded from the same patients by an asylum doctor and 'a constant observer' in 1823: the implications for theories about psychiatric illness in history. Hist Psychiatry. 1992;3:79-94.

36. Hare E. Was insanity on the increase? Br J Psychiatry. 1983;142:439-55, quoting Harper.

37. Carpenter PK. Descriptions of schizophrenia in the psychiatry of Georgian Britain: John Haslam and James Tilly Matthews. Compr Psychiatry. 1989;30:332-8.

38. Leigh D. The historical development of British Psychiatry. Vol I. Oxford: Pergamon; 1961. p. 122.

39. Cox J. Practical observations on insanity. London: Baldwin; 1804.

40. Stark W. Remarks on the construction of public hospitals for the cure of mental derangement. Edinburgh: Ballantyne; 1807.

41. Reid J. Report of diseases. Monthly Magazine. 25(1808):166, 374.

42. Byrd M. Visits to Bedlam: Madness in literature in the 18th century. Columbia: University of South Carolina Press. 1974. p. 128.

43. House of Commons, Report of the Select Committee on the State of Criminal and Pauper Lunatics, 1807.

44. Jones K. A history of the mental health services. London: Routledge and Kegan Paul; 1972. p. 58.

45. Powell R. Observations upon the comparative prevalence of insanity at different periods. Med Transact. 1813;4:131-59.

46. Smith LD. Cure, comfort and safe custody: public lunatic asylums in early nineteenth century England. London: Leicester University Press; 1999. p. 24.

47. Crammer J, A silent history: Buckinghamshire County Pauper Lunatic Asylum-St. John's. London: Gaskell, Royal College of Psychiatrists; 1990. p. 15.

48. Skultans V. English madness: ideas on insanity, 1580-1890. London: Routledge and Kegan Paul; 1979. p. 98.

49. Smith LD. Cure, comfort and safe custody: public lunatic asylums in early nineteenth century England. London: Leicester University Press; 1999. p. 39.

50. Smith LD. Cure, comfort and safe custody: public lunatic asylums in early nineteenth century England. London: Leicester University Press; 1999. p. 40-1.

51. Hare E. Was insanity on the increase? Br J Psychiatry. 1983;142:439-55, quoting Crowther.

52. Hill G. An essay on the prevention and cure of insanity. London: Longman, Hurst, Rees, Orme and Brown; 1814.

53. Simond L. An American in regency England. London: Robert Maxwell; 1815. p. 110, 115.

54. Arnold T. Observations on the nature, kinds, causes, and prevention of insanity, lunacy or madness. New York: Arno Press; 1976.; Originally published in 1782. p. 17-27.

55. Arnold T. Observations on the nature, kinds, causes, and prevention of insanity, lunacy or madness. New York: Arno Press; 1976.; Originally published in 1782. p. 26.

56. Rowley W. A treatise of female, nervous, hysterical, hypochondriacal, bilious, convulsive diseases. London: C. Nourse; 1788. p. 253-4.

57. Porter R, editor. The Faber book of madness. London: Faber and Faber; 1991. p. 120.

58. Scull A. The most solitary of afflictions. New Haven: Yale University Press; 1993. p. 157.

59. Porter R. Mind-forged manacles: A history of madness in England. Cambridge: Harvard University Press, 1987; p. 161.

60. Browne WAF. What asylums were, are, and ought to be. Edinburgh: Black; 1837; New York: Arno Press; 1976. p. 52.

61. Moore CA. Backgrounds of English literature. New York: Octagon books; 1969. p. 190.

62. Simond L. An American in regency England. London: Robert Maxwell; 1815. p. 110.

63. Browne WAF. What asylums were, are, and ought to be. Edinburgh: Black; 1837; New York: Arno Press; 1976. p. 61.

64. Scull A. The most solitary of afflictions. New Haven: Yale University Press; 1993. p. 158.

65. Pinel PA. Treatise on insanity. Sheffield: Todd; 1806. p. 114.

66. Courtney WF. Young Charles Lamb, 1775-1802. New York: New York University Press; 1982. p. 108, 110, quoting Lamb's letters to Coleridge. 
67. Courtney WF. Young Charles Lamb, 1775-1802. New York: New York University Press; 1982. p. $114,115$.

68. Lucas EV, editor. The letters of Charles Lamb, vol. 3. New Haven: Yale University Press; 1935. p. 370, 417.

69. Lucas EV, editor. The letters of Charles Lamb, vol. 3. New Haven, Yale University Press; 1935. I, 9.

70. Jamison KR, Touched with fire: Manic-depressive illness and the artistic temperment. New York: Free Press; 1993. p 67, 221.

71. Faulkner TC, editor. Selected letters and journals of George Crabbe. Oxford: Clarendon Press; 1985. p. 102.

72. Shimer M. Madness and the muse in nineteenth-century English romantic poetry. Ann Arbor: UMI Dissertation Service; 1996. p. 73.

73. Shimer M. Madness and the muse in nineteenth-century English romantic poetry. Ann Arbor: UMI Dissertation Service; 1996. p. 127.

74. Youngquist P. Madness and Blake's myth. University Park: Pennsylvania State University Press; 1989. p. 3, 16, 105-107, 170n.

75. Ackroyd P. Blake. London: Vintage; 1995. p. 233.

76. Whitehead F. George Crabbe: a reappraisal. Selinsgrove: Susquehanna University Press; 1995. p. 50.

77. Pollard A, editor. Crabbe: the critical heritage. Boston: Routledge and Kegan Paul; 1972. p. 53, quoting the Oxford review, January 1808.

78. Whitehead F. Crabbe: a reappraisal. Selinsgrove: Susquehanna University Press; 1995. p. 143.

79. Shimer M. Madness and the muse in nineteenth-century English romantic poetry. Ann Arbor: UMI Dissertation Service; 1996. p. 200.

80. Jamison KR, Touched with fire: Manic-depressive illness and the artistic temperment. New York: Free Press; 1993. p. 179, 2, 43, 171.

81. Jamison KR, Touched with fire: Manic-depressive illness and the artistic temperment. New York: Free Press; 1993. p. 179, 69.

82. Jamison KR, Touched with fire: Manic-depressive illness and the artistic temperment. New York: Free Press; 1993. p. 67.

83. Oberhelman DD. Mad encounters: nineteenth-century British psychological medicine and the Victorian novel, 1840-1870. Ann Arbor: UMI Dissertation Services; 1993. p. 87.

84. Buck HM. Insanity, character roles, and authorial milieu: a study of madness in selected Waverley novels. Ann Arbor: UMI Dissertation Services; 1987. p. 30.

85. Claridge G, Pryor R, Watkins G. Sounds from the bell jar. New York: St. Martin's Press; 1990. p. 132-3.

86. Haughton H, editor. John Clare in context. Cambridge: Cambridge University Press; 1994. p. 10.

87. Quiller-Couch AT, editor. The Oxford book of English verse 1250-1900. Oxford: Clarendon Press; 1907.

88. Colley AC. Tennyson and madness. Athens: University of Georgia Press; 1983. p. 258, 266.

89. Bucknill JC. Maud and other poems, by Alfred Tennyson. Asylum J Ment Sci. 15 (1855): 94-104. Tennyson AL, The works of Tennyson, vol. 4, The Princess and Maud. New York: AMS Press; 1970. p. 209.

90. Bronte C. Jane Eyre. New York: Penguin Books; 1982. p. 295.

91. Small H. Love's madness: medicine, the novel, and female insanity, 1800-1865. Oxford: Clarendon Press; 1996. p. 165, quoting Bronte's letter of January 4, 1848.

92. Colley AC. Tennyson and madness. Athens: University of Georgia Press; 1983. p. 10.

93. Small H. Love's madness: medicine, the novel, and female insanity, 1800-1865. Oxford: Clarendon Press; 1996. p. 165, quoting Bronte's letter of January 28, 1848.

94. Mannheim L. Dickens' fools and madmen. Dickens Stud Ann. 1972;2:69-97.

95. Dickens C. The works of Charles Dickens: Pickwick papers, vol. 208. New York: Books, Inc; 1841. 
96. Oberhelman DD. Mad encounters: nineteenth-century British psychological medicine and the Victorian novel, 1840-1870. Ann Arbor: UMI Dissertation Services; 1993. p. 381, 393, 389.

97. The works of Charles Dickens: Barnaby Rudge. New York: Books, Inc.; 1841. p. 521.

98. Dickens C. A curious dance. Household Words. January 17, 1852.

99. Dickens C, Collins W. The lazy tour of two idle apprentices. In: Seaside library, vol. XIX, no. 372. New York: George Munro; 1857.

100. Oberhelman DD. Mad encounters: nineteenth-century British psychological medicine and the Victorian novel, 1840-1870. Ann Arbor: UMI Dissertation Services; 1993. p. 132-3.

101. Oberhelman DD. Mad encounters: nineteenth-century British psychological medicine and the Victorian novel, 1840-1870. Ann Arbor: UMI Dissertation Services; 1993. p. 126-127, $179,198$.

102. Skilton D. Introduction to Lady Audley's secret, by Mary Elizabeth Braddon. Oxford: Oxford University Press; 1987.

103. Braddon ME. Lady Audley's secret. Harmondsworth: Penguin; 1985. p. 293.

104. Entries on Wikipedia for John Robert Cozene, Lemuel Abbott, James Gillray, and Richard Dadd.

105. Scull A, et al. Masters of bedlam. Princeton: Princeton University Press; 1996. p. 97.

106. Burrows GM. Commentaries on the causes, forms, symptoms, and treatment, moral and medical, of insanity. New York: Arno Press; 1976.; Originally published in 1828. p. 81.

107. Burrows GM. An inquiry into certain errors relative to insanity. London: Underwood; 1820. p. 54.

108. Burrows GM. An inquiry into certain errors relative to insanity. London: Underwood; 1820. p. $80,81,83$.

109. Macalpine I, Hunter R. George III and the Mad Business. London: Pimlico; 1991. p. 294.

110. Anonymous. Inquiries relative to insanity. Q Rev. 24(1821):181.

111. Anonymous. Insanity. Q Rev. 1830;42:351-77.

112. Halliday A. A report on the number of lunatics and idiots in England and Wales. In: A letter to Lord Robert Seymour. London: Underwood; 1829.

113. Halliday A. A general view of the present state of lunatics, and lunatic asylums. London: Underwood; 1828. p. 80.

114. Prichard J. A treatise on insanity and other disorders affecting the mind. London: Sherwood, Gilbert and Piper; 1835. p. 350.

115. Scull A, et al. Masters of bedlam. Princeton: Princeton University Press; 1996. p. 89, 97, 103.

116. Report of the metropolitan commissioners in lunacy to the Lord Chancellor. London: Bradbury and Evans; 1844. Appendix F.

117. Jones K. A history of the mental health services. London: Routledge and Kegan Paul; 1972. p. 227.

118. Smith LD. Cure, comfort and safe custody: public lunatic asylums in early nineteenth century England. London: Leicester University Press; 1999. p. 176-7.

119. Parry-Jones W. The trade in Lunacy: a study of the private madhouses in England in the 18th and 19th centuries. London: Routledge and Kegan Paul; 1972; p. 65.

120. Colley AC. Tennyson and madness. Athens: University of Georgia Press; 1983. p. 12.

121. Scull A. Psychiatrists and historical 'facts': part two: re-writing the history of asylumdom. Hist Psychiatry. 1995;6:387-94.

122. Jones K. A history of the mental health services. London: Routledge and Kegan Paul; 1972. p. 89.

123. Walton JK. Casting out and bringing back in Victorian England: pauper lunatics, 1840-1870. In: Bynum et al. Anatomy of madness, vol. 2. p. 132.

124. Hare E. Was insanity on the increase? Br J Psychiatry. 1983;142: 439-55, quoting John Arledge.

125. Scull A. The most solitary of afflictions. New Haven: Yale University Press; 1993. p. 268 , note 2 .

126. Crammer J. Asylum history. London: Gaskell; 1990. p. 38-9. 
127. Haguch. Comments on the report of the commissioners in lunacy and the swing of the pendulum. Westminster Rev. 1897;148:672-81.

128. Ayers GM. England's first state hospitals and the metropolitan asylums board, 1867-1930. London: Wellcome Institute; 1971. p. 38.

129. Jones K. A history of the mental health services. London: Routledge and Kegan Paul; 1972. p. 124.

130. McCandless P. 'Build! Build!': The controversy over the care of the chronically insane in England, 1855-1870. Bull Hist Med. 1979;53:553-74.

131. Hodgkinson, "Provision for pauper lunatics."

132. Scull A. The most solitary of afflictions. New Haven: Yale University Press; 1993. p. 160.

133. Burnett CM. Insanity tested by science. London: Highley; 1848.

134. Anonymous. Familiar views of lunacy and lunatic life. London: Parker; 1850. p. 101-2.

135. Maddox AB. Practical observations on nervous and mental disorders. London: Simpkin, Marshall; 1854. p. 13.

136. Hawkes J. On the increase of insanity. J Psychol Med Mental Pathol. 1857;10:508-21.

137. The Times, August 6, 1850, $5 \mathrm{f}$.

138. "Horrible Circumstance": The Times, October 7, 1844, 4 f.

139. Anonymous. 13th Report of the commission on lunacy. J Ment Sci. 1860;6:141-56.

140. Report of the Select Committee, 1859, Appendix 7, 324, quoted in W. J. Corbet. The holocaust at Colney Hatch. Westminster Rev. 159(1903):383-93.

141. Bucknill JC, Tuke DH. A manual of psychological medicine. London: Churchill; 1858. p. 32, 108.

142. Robertson CL. Lunacy in England. J Psychol Med Ment Pathol. 7(1881):185-6. The alleged increase of lunacy. J Ment Sci. 15(1869):1-23.

143. Journal of Mental Science 15 (1869):317-318, 446-447.

144. Journal of Mental Science 16 (1871):481, 492.

145. Robertson CL. Lunacy in England. J Psychol Med Ment Pathol. 7(1881):185-6. The alleged increase of lunacy. J Ment Sci. 15(1869):1-23.

146. Scull A. The most solitary of afflictions. New Haven: Yale University Press; 1993. p. 337-8.

147. The Times. January 11, 1860; August 2, 1868. April. June 30, 1864;5:1877.

148. Anonymous. The increase in lunacy. North Br Rev. 50(1869):123.

149. Scull A, et al. Masters of bedlam. Princeton: Princeton University Press; 1996. p. 233.

150. Maudsley H. Is insanity on the increase? Br Med J. 1872;1:36-9.

151. Maudsley H. The alleged increase of insanity. J Ment Sci. 1877;23:45-54.

152. Asylum reports. J Ment Sci. 44(1898):195.

153. Parker RR, et al. County of Lancaster Asylum, Rainhill: 100 years ago and now. Hist Psychiatry. 1993;4:95-105.

154. Turner T. Rich and mad in Victorian England. Psychol Med. 1989;19:29-44.

155. Renvoize EB, Beveridge AW. Mental illness and the late Victorians: a study of patients admitted to three asylums in York, 1880-1884. Psychol Med. 1989;19:19-28.

156. Klaf F, Hamilton J. Schizophrenia-a hundred years ago and today. J Ment Sci. 1961;107:819-27.

157. Parry-Jones W. The trade in Lunacy: a study of the private madhouses in England in the 18th and 19th centuries. London: Routledge and Kegan Paul; 1972. p. 328-330.

158. Wilkins R. Hallucinations in children and teenagers admitted to Bethlem Royal Hospital in the nineteenth century and their possible relevance to the incidence of schizophrenia. J Child Psychol Psychiatry. 1987;28:569-80.

159. Tuke DH. A dictionary of psychological medicine. Philadelphia: Blakiston; 1892.

160. Mitchell A. Contribution to the study of death rates of persons in asylums. J Ment Sci. $1879 ; 25: 1-4$.

161. Lunacy commission report. J Ment Sci. 52(1906):142-7.

162. Walton J. The treatment of pauper lunatics in Victorian England: the case of Lancaster asylum 1816-70. In: Scull A, editor. Madhouses, mad-doctors, and madmen: the social history of psychiatry in the Victorian era. Philadelphia: University of Pennsylvania Press; 1981. p. 171. 
163. Scull A, et al. Masters of bedlam. Princeton: Princeton University Press; 1996. p. 234.

164. Scull A. The most solitary of afflictions. New Haven: Yale University Press; 1993. p. 325.

165. Bynum WF. Tuke's dictionary and psychiatry at the turn of the century. In: Berrios GE and Freeman H, 150 Years of British Psychiatry, 1841-1991. London: Royal College of Psychiatrists; 1991. p. 164.

166. Tuke DH. Alleged increase of insanity. J Ment Sci. 1894;40:219-31.

167. Tuke DH. Chapters in the history of the insane in the British isles. London: Kegan Paul, Trench; 1882. p. 261.

168. Tuke DH. Alleged increase of insanity. J Ment Sci. 1894;40:219-31. Tuke DH. Chaptes in the history of the insane in the British isles. London: Kegan Paul, Trench; 1882. Hare E. Was insanity on the increase? Br J Psychiatry. 1983;142.

169. Psychological retrospect. Am J Insanity. 30(1874):476-7. Tuke H. Presidential address. J Ment Sci. 19(1873):327-40 and 479-85.

170. The works of Charles Dickens: our mutual friend. New York: Books, Inc.; 1841. p. 130.

171. Jones K. Lunacy, law and conscience 1744-1845. London: Routledge and Kegan Paul; 1955. p. 116.

172. Lunacy Commission reports: "Lunacy in England," The Times, January 4, 1878, $6 \mathrm{f}$. Allderidge P. Hospitals, madhouses and asylums. Brit J Psychiatry. 1999;134:321-34.

173. Scull A. The most solitary of afflictions. New Haven: Yale University Press; 1993. p. 209.

174. Robertson CL. A further note on the alleged increase of insanity. J Ment Sci. 1871;16:473-97.

175. Duncan PM. On insanity. J Sci. 1870;7:165-86.

176. Hare E. Was insanity on the increase? Br J Psychiatry. 1983;142:439-55.

177. Humphreys NA. Statistics of insanity in England. J R Stat Soc. 1890;53:201-52.

178. Special report on the alleged increase of insanity. 1897, 16.

179. J Ment Sci. 44(1898):113-26.

180. J Ment Sci. 45(1899):139-48.

181. Haguch. Comments on the report of the commissioners in lunacy and the swing of the pendulum. Westminster Rev. 1897;148:672-81.

182. Corbet WJ. Plain speaking about lunacy. Westminster Rev. 148(1897):117-25; The increase of insanity. 1896; The increase of insanity. Fortnightly Rev. 59 (n.s. 53) (1893):7-19.

183. The Times, August 28, 1903, 7 f. "56th Report," J MentaSci. 49(1903):126.

184. Briggs A. A social history of England. New York: Penguin; 1999. p. 216, 245.

185. Crammer J. Asylum history. London: Gaskell; 1990. p. 75.

186. Crammer J. Asylum history. London: Gaskell; 1990. p. 77.

Open Access This chapter is licensed under the terms of the Creative Commons AttributionNonCommercial-NoDerivatives 4.0 International License (http://creativecommons.org/licenses/ by-nc-nd/4.0/), which permits any noncommercial use, sharing, distribution and reproduction in any medium or format, as long as you give appropriate credit to the original author(s) and the source, provide a link to the Creative Commons license and indicate if you modified the licensed material. You do not have permission under this license to share adapted material derived from this chapter or parts of it.

The images or other third party material in this chapter are included in the chapter's Creative Commons license, unless indicated otherwise in a credit line to the material. If material is not included in the chapter's Creative Commons license and your intended use is not permitted by statutory regulation or exceeds the permitted use, you will need to obtain permission directly from the copyright holder. 